\title{
Accounting in Bhopal: Making \\ Catastrophe
}

\author{
Sumohon Matilal
}

The York Management School, University of York

and

Pawan Adhikari

Essex Business School, University of Essex 


\begin{abstract}
The study examines the pervasive role of accounting constructs in the machinations of catastrophe. Using the 1984 Bhopal Gas Tragedy in India as a case, we draw upon the notions of performativity and paralogy advocated by Jean-François Lyotard (1979 trans. 1984), in his seminal work "The Postmodern Condition: A Report on Knowledge", to showcase how a preoccupation with the maximisation of efficiency, predicated on an illusion of complete control over the system, paved the way for entropy and disaster. Combining document analysis and interviews with key participants, we develop what Lyotard (1984) terms as a petit recit or little narrative, which offers a paralogical evaluation of the tragedy based on dissensus, incorporating conflicting multiple perspectives that suggest the deep-seated nature of accounting constructs in the design of catastrophe. In the process we develop a locally rooted alternative interpretation of the events that preceded the disaster and question the facade of responsibility and safety professed by the 1984 Annual Reports of the Union Carbide Corporation and Union Carbide India Limited.
\end{abstract}

\title{
Keywords
}

Catastrophe, Bhopal, Lyotard, Performativity 


\section{Introduction}

"Let us wage a war on totality; let us be witnesses to the unpresentable; let us activate the differences and save the honour of the name"

Lyotard (1984, p. 82)

December 3, 1984. 12:30am. A tank explodes in a pesticide factory in Bhopal, India, resulting in the release of 40 tons of methyl isocyanate, a highly toxic, deadly gas. The colourless gas is heavier than air. It settles into a dense cloud and stays close to the ground as it silently spreads into the nearby shanty towns and then into the other parts of the city. The vast majority of the Bhopalis are sleeping. Some wake up feeling choked, start coughing uncontrollably and convulsing. Some find that they cannot see anymore, experience tremendous chest pain and shortness of breath. Some never wake up again. People panic and start fleeing their homes, thinking that the end of the world has come. There is complete chaos and soon a stampede ensues.

The purpose of this paper is to critically evaluate the pervasive role of accounting constructs in the making of catastrophe. We draw upon the notion of performativité (performativity), introduced by Jean-François Lyotard in his seminal work, La condition postmoderne: rapport sur le savoir (The Postmodern Condition: A Report on Knowledge) (1979 trans. 1984), to examine how an obsession with the maximisation of efficiency, actualised through the calculative mechanisms of accounting, sustained an illusion of complete control over a system and led to entropy and disaster, in the case of the 1984 Bhopal Gas Tragedy.

In the Postmodern Condition, Lyotard (1984) argues that the advent of capitalism and the increased use of technology have led to postmodern societies being characterised by the decline of the grand narratives of modernity and the rise of a preoccupation with increasing 'performativity', which he defines as efficiency measured in terms of the best input/output ratio. Studying the social collective through language games (Wittgenstein, 1963), he observes that the power of the performativity criterion is such that it stifles the heterogeneous nature of discourse. If anything is deemed inefficient, it is marginalised from discourse. Lyotard (1984) calls this process of exclusion arising from the consensus to maximise efficiency, the 'terror of performativity'. To contest the hegemony of the performativity criterion, he proposes legitimation by paralogie (paralogy) - a movement against the established ways of reasoning, the search of instabilities, concentrating on the unknown rather than the known (p. 60). This entails a continuous quest for alternative interpretations and a focus on difference and heterogeneity. 
Postmodern approaches are not new to critical accounting scholarship. Several studies have drawn upon the works of eminent postmodern thinkers such as Michel Foucault (e.g., Hoskin \& Macve, 1988,1994; Miller \& O’Leary, 1987; Rose, 1991), Jacques Derrida (e.g., Arrington \& Francis, 1989; Ezzamel \& Hoskin, 2002; McKernan \& Kosmala 2007) and Jean Baudrillard (e.g., Macintosh, Shearer, Thornton \& Welker, 2000 ; Mattessich 2003; Gumb, Dupuy, Baker \& Blum, 2018). Though considered to be one of the most influential and radical postmodern thinkers (Koornhof \& De Villiers, 1999), very few accounting scholars have drawn upon the work of Jean-François Lyotard as a theoretical lens. These include the work by Cooper (1997) who is critical of Lyotard's postmodern approach for its pluralistic focus and inability to show how specific ideas rationalise forms of political domination and that by Savage (1995) who compares Thomas Kuhn's modern approach to science with Lyotard's postmodern perspective to suggest that the emergence of postmodern trends in critical accounting research is characterised by competing paradigms and fragmentation.

In this paper, we argue that Lyotard's (1984) work is particularly useful for understanding the pervasive role of accounting in the machinations of industrial disasters. This is because accounting and the notion of economic efficiency as suggested by Lyotard (1984) are intrinsically linked. As the language of the capitalist system (Sikka, 2015), accounting constructs concretise the parameters for judging what is efficient, i.e. profitable and what is not, in postmodern discourse. Lyotard's (1984) work helps us evaluate how and why, during the long incubation periods typical of industrial disasters, a fixation with maximising efficiency (profitability) translates to a marginalisation of issues such as safety, maintenance and staff training, eventually leading to catastrophe. By exposing the horrific consequences of the terror of performativity, such an evaluation makes an alternative interpretation of disaster possible, one which questions the official explanations of industrial disasters being sheer accidents. As observed by Koornhof and De Villiers (1999), like most radical postmodernists, Lyotard (1984) also argues for a pluralistic world, where there are no singular truths and there is no generalising and closure. This is of particular relevance in case of a disaster scenario when multiple realities collide and compete with each other (Perkiss \& Moerman 2017, 2018). It is therefore important to showcase the multiplicity of perspectives which promote dissensus rather than consensus so that the quest for alternative explanations can continue. In sum, as Cooper (1997, p. 26) observes, Lyotard's (1984) approach enables an appreciation of "the use of the rhetoric of efficiency" as a legitimising device and refines our sensitivities to plurality.

The role of accounting in relation to disasters has drawn significant attention of accounting scholars in recent years. However, this emerging literature on accounting and disasters has a predominantly post-disaster focus that can be further grouped into two categories - research that focuses on examining post-disaster accountability and that which focuses on the role of accounting in post-disaster relief. For example, scholars such as Baker (2014) and Taylor, Tharapos \& Sidaway (2014) study the nature of accountability of governmental agencies and non-governmental organisations post Hurricane Katrina. Perkiss \& Moerman (2017, 2018) 
develop a disaster narrative to demonstrate how multiple realities collide and compete with each other in the aftermath of Hurricane Katrina and climate change in the Pacific Islands. Agyenim-Boateng \& Oduro-Boateng (2019) draw upon the 2015 floods and fire in Accra, Ghana to examine the lack of accountability among the various parties involved in the disaster management process. Studies focusing on the role of the calculative technologies of accounting in post-disaster relief include the work of Sargiacomo, Ianni \& Everett (2014) who examine how the changing accounting requirements complicated the resettlement of the 2009 Abruzzo earthquake victims. Sargiacomo (2015) also draws upon the Abruzzo earthquake to show how accounting schemes were not only instrumental in defining the earthquake as a disaster, they also formed the basis of an extraordinary governmental response. In a similar vein, Lai, Leoni \& Stacchezzini (2014) and Walker (2014) delineate the positive role that accounting technologies played in the post-disaster relief.

Relatively fewer scholars have examined accountability in the context of industrial disasters. Matilal \& Höpfl (2009) examine the Bhopal Gas Tragedy in India in 1984, arguing that photographs can play a complementary role to financial statements to provide better accountability. Cooper, Coulson \& Taylor (2011) study the ICL Plastics plant disaster in Scotland in 2004 to argue for the development of a new way of accounting for human rights. Questioning governmental accountability in the case of the Rana Plaza disaster, Siddiqui \& Uddin (2016) show how the State-business nexus perpetuates the violation of human rights in the ready-made garments industry in Bangladesh. Amernic \& Craig (2017) explore the role played by CEO language in adversely influencing the safety culture at British Petroleum preceding the Deepwater Horizon disaster. More recently, Cooper \& Lapsley (2019) have drawn upon the 1989 Hillsborough disaster to examine poor public accountability vis-à-vis the relentless struggle for justice for those who died and for their families.

Our contribution in this paper is three-fold. First, we contribute to the growing scholarship on accounting and disasters. We draw upon the 1984 Bhopal Gas Tragedy to examine the role of accounting constructs in the design of catastrophe. Studies examining the role of accounting in the formulation of a disaster, i.e. in the pre-catastrophe stages, are scarce, as illustrated above. Second, we introduce Lyotard's concepts of performativity and legitimation by paralogy to accounting research. We carry out a paralogical evaluation of the 1984 UCC and UCIL Annual Reports published in the immediate aftermath of the Bhopal Gas disaster. We draw upon internal documents and interviews with former employees and victims to create what Lyotard terms a petit recit or little narrative on the tragedy that contests the claims of safety and responsibility advocated by the annual reports. Our narrative is locally rooted, incorporates multiple conflicting perspectives and is in the spirit of Lyotard's (1984) focus on dissensus, incomplete. It suggests how an obsession with performativity actuated through accounting constructs, led to possible compromises in training, maintenance and safety, contributing to the tragedy. Third, we add to the existing scholarship on the Bhopal Gas Tragedy. As will be discussed in section four, while the tragedy has been studied from multiple angles, the role played by accounting constructs in its formulation remains underresearched. 
The rest of the paper is organised as follows. The following section discusses the seminal work of Jean-François Lyotard (1984), The Postmodern Condition: A Report on Knowledge, which has provided a theoretical lens for our study. Section three outlines the method adopted in the paper. This is followed by a discussion of our case, the 1984 Bhopal Gas Tragedy, in section four. Section five examines the 1984 annual reports of the Union Carbide Corporation and Union Carbide India Limited and then section six offers a paralogical evaluation, along the lines advocated by Lyotard (1984). Finally, in section seven, we offer our concluding remarks.

\section{Theoretical Framing}

A postmodern approach requires the researcher to challenge the dominant paradigms of knowledge and develop new paradigms by taking cognisance of voices that do not find a place in the dominant discourses (see Harvey, 1989; Rosenau, 1992; Kilduff \& Mehra 1997; Giroux, 1992). One of the most influential works on postmodernism is The Postmodern Condition: A Report on Knowledge, by Jean-François Lyotard (1979 trans. 1984) where Lyotard argues that in most European societies, since the end of the 1950s, the status of knowledge has been altered as these societies entered the postindustrial age and cultures entered the postmodern age (p. 3). He uses the word 'postmodern' to describe the condition of knowledge in postindustrial societies and defines it as "incredulity toward metanarratives" (p. xxiv).

According to Lyotard (1984), modern knowledge seeks legitimation by appealing to the metanarratives of the Enlightenment, religion, progress and emancipation, dialectics of Spirit, creation of wealth and so forth. These metanarratives attain the status of universal metaprescriptions that determine what is admissible as knowledge and what is to be excluded. In contrast, postmodern knowledge is sceptical of any form of totalising thought. Lyotard attributes such scepticism to the technological progress in postindustrial society, characterised by the "hegemony of computers" (p. 4). However, such technological advancements have had a profound impact on the two principal functions of knowledge - research and the transmission of learning. In terms of research, Lyotard argues that since the 1950s, most developments in the leading sciences and technologies have been language based e.g. theories of linguistics, cybernetics, informatics and telematics. Second, computerisation has completely changed the way knowledge is acquired and transmitted. Knowledge is of use only if it can be miniaturised and made available through computing machines. As a consequence, the status of knowledge has changed permanently - it has ceased to become an end in itself and is now a commodity that is traded for commercial advantage. Knowledge is now produced to be sold (Case and Piñeiro 2006, p. 763). For Peters (1997, p. 14), Lyotard showcases how capitalism has penetrated language, transforming phrases to encoded messages with an exchange value. 
Lyotard (1984, p. 46) further argues that the rise of capitalism and the increased use of technology in the production of knowledge is rooted in the intention to increase performativity ${ }^{l}$, which he defines as efficiency measured according to the best input/output ratio. In postindustrial societies, he posits, research is not a quest for true knowledge but that for the most efficient performance. In contrast to the modern, there is no metanarrative of progress or emancipation driving the production of knowledge in postmodern society. Instead, there is continuous brainstorming on how to improve performance (p. 52). As scholars such as Case and Piñeiro (2006, p. 763) and Irving (2015, p. 6) observe, an economic episteme, based on the principle of optimal performance reigns supreme. Debate over the purpose of knowledge is no longer on the agenda; what matters more is achieving maximum output with minimum input.

The dominance of the performativity criterion results in an exclusion of that which is deemed inefficient. Using language games (Wittgenstein, 1963) as his methodological approach, Lyotard (1984, p. 65) argues that the social collective is "a monster" characterised by heteromorphous language games. However, the "...quest for the most performative unity possible" (p. 63) stifles heterogeneity, distinguishing institutional discourse from a freeflowing conversation. As Lyotard (1984, p. 17) observes:

"[A]n institution differs from a conversation in that it always requires supplementary constraints for statements to be declared admissible within its bounds. The constraints function to filter discursive potentials, interrupting possible connections in the communication networks: there are things that should not be said. They also privilege certain classes of statements (sometimes only one) whose predominance characterizes the discourse of the particular institution: there are things that should be said, and there are ways of saying them. Thus: orders in the army, prayer in church,...performativity in businesses [emphasis added].”

\footnotetext{
${ }^{1}$ It needs to be noted here that the notion of performativity introduced by Lyotard (1984) in the Postmodern Condition is different from that developed by Michel Callon $(1998,2007)$ in relation to Callonistics or the performativity thesis, increasingly used by accounting scholars (see for example Vosselman, 2014; Revellino \& Mouritsen, 2015). Callon extends John L. Austin's (1962) notion of performativity which the latter describes as an utterance, "in which to say something is to do something; or in which by saying something we are doing something" (p. 12). Callon (2007) applies this concept of performativity to economics to argue that economic statements have performative power; they actively constitute the reality that they describe. Lyotard (1984), however, refers to performativity in terms of economic efficiency. In fact, he distinguishes his notion of performativity from that of Austin (1962) in the Postmodern Condition:
}

"The term performative has taken on a precise meaning in language theory since Austin. Later in this book, the concept will reappear in association with the term performativity (in particular, of a system) in the new current sense of efficiency measured according to an input/output ratio." (Lyotard 1984, n.88)

Thus, for Lyotard (1984), performativity is the maximisation of efficiency, “...the production of maximum output for minimum input" (Fournier \& Grey 2000, p. 17). As Cabantous et al. (2016, p. 200) suggest, the use of a similar term i.e. performativity, by Austin (1962) and Lyotard (1984) is entirely coincidental. 
Any attempt to destabilise the accepted norms, defined and legitimised by the performativity criterion, is marginalised from institutional discourses because it challenges the rules of the game i.e. maximum output with minimum input, upon which the consensus of the players are based.

A similar observation can be made about financial reporting, where the maximisation of efficiency (shareholder value) drives the organisational account, marginalising issues that cannot be legitimised by this criterion. This is particularly significant in a catastrophic scenario where multiple realities collide and dissensus is the norm (Perkiss \& Moerman, 2017). However, dissensus and heterogeneity are ironed out from the post disaster financial reports by the organisational consensus on the primacy of the interests of the providers of capital.

Accounting, arguably, serves as the mechanism for conceptualising Lyotard's notion of performativity in postmodern society, being the language of the capitalist system (Belkaoui 1978; Chiapello 2007). Constructs such as profits, cash flows, returns etc., as performance indicators, concretise the notion of high/low efficiency and in turn, determine the flow of capital. Activities that can be measured in terms of these constructs therefore gain prominence in social discourse while those that cannot fade into oblivion. For example, in the context of the transmission of knowledge, Lyotard (p. 51) observes that the questions increasingly asked by the student or the university are, "Is it saleable? Is it efficient?" He continues to argue that in postmodern society, given the dominance of the performativity criterion, competence in a performance-oriented skill is indeed more saleable, and more efficient. Thus performativity, through accounting constructs, functions as an agenda-setting device in social discourse. In the accounting literature, parallels can be found in the work of scholars such as Hines (1992) who argues that the language of accounting entails a material reductionism - only that which can be quantified, measured and expressed using accounting constructs is granted visibility and then used to define organisational reality. In other words, to be visible, one has to speak in terms of this language (Killian, 2010) or be consigned to the margins.

For Lyotard (p. xxiv), the stifling of the heterogeneous nature of discourse by the performativity criterion, constitutes "...a certain level of terror, whether soft or hard: be operational (that is commensurable) or disappear". This element of terror, arguably the consequences of which are manifested in the form of various crises, showcases the power of the performativity criterion in postmodern society. Lyotard (p. 46) observes that power is good performativity; it legitimises on the basis of efficiency - something is true because it is efficient i.e. profitable. The power of performativity, as Lyotard (p. 47) argues, “...legitimises science and law on the basis of their efficiency and legitimates this efficiency on the basis of science and law." In the process, an equation is established between wealth, efficiency and truth. The language of accounting renders a crucial role in establishing and institutionalising this equation. The facade of numerical efficiency associated with accounting constructs and the notion of 
profitability, as an unproblematic benchmark of success, are collectively mobilised by the providers of capital to celebrate economic rationality as truth, masking real social problems in the process. This is particularly evident in various crisis settings, including war (Gallhofer \& Haslam, 1991; Funnell, 1998), crime (Lehman \& Okcabol, 2005), and privatisation (Craig \& Amernic, 2008; Cooper 1997).

Lyotard (p. 54) further argues that performativity, as an input/output ratio, presumes that society is a highly stable system. Once an input is entered, the stable system would follow a linear trajectory, as a continuous function, allowing an accurate, calculable, prediction of the output. The logic behind such a presumption being that a system's performance can be predicted accurately, if, firstly, all the variables are known in advance and secondly, there exists perfect control over its functioning such that it follows a regular path, achieving the output that was predicted. For Lyotard (1984) such a quest for totality is not only utopian but also inefficient. He states that an exact definition of all the independent variables constituting a system, is next to impossible since no such definition can be effected.

We wish to argue that the calculus of accounting, as a conduit through which performativity is actualised, creates and sustains the illusion of a stable system where all the variables are known in advance and where there exists perfect control over its functioning. The definitions of an accountant purport to define a multifaceted organisation in its totality (Hines, 1988), negating the fact that in reality only those aspects of the organisation that can be measured in quantitative terms are being catered to (Hines, 1992). Furthermore, the trajectory designed by the accountant to achieve targeted profits, cash flows etc. with the objective of optimising the input/output equation, unilaterally, defines the direction of the organisation, explaining the relentless pursuit of profits as the only measure of organisational success in postmodern society. However, the illusion of total control over the organisational system through partial numerical constructs breaks when the anticipated trajectory for continuous growth and expansion turns out to be unachievable and predictions regarding future profits, cash flows etc. go awry, paving the way for entropy and crisis.

\section{Contesting the hegemony of performativity}

According to Gond, Cabantous, Harding \& Learmonth (2016, p. 10), by problematising performativity, Lyotard (1984) wants us to critically evaluate the effects of the preoccupation with efficiency in postmodern society. While scholars are in disagreement over whether Lyotard is proposing performativity as the new grand narrative (Nola \& Irzik, 2003), a key concern is how to challenge the consensus imposed by the performativity criterion? If any consensus is based on exclusion, how does one restore the heterogeneity in postmodern discourse? (Peters, 1997, p. 17). According to Lyotard (1984, p. 66), there is no "pure" alternative as it would end up becoming just another modernist metanarrative. Instead he 
proposes legitimation by paralogy, a movement against the established ways of reasoning, the search for instabilities, focussing on the unknown rather than the known (p. 60). Although Lyotard does not provide an exact method for legitimising through paralogical reasoning, it is possible to tease out the essence of his argument from the following paragraph:

"The function of the differential or imaginative or paralogical activity of the current pragmatics of science is to point out these metaprescriptives and to petition the players to accept different ones (italics added). The only legitimation that can make this kind of request admissible is that it will generate ideas, in other words, new statements." (p. 65)

In other words, paralogical reasoning in postmodern science entails exposing the metanarrative/framework in which previous scientific progress had taken place (Peters, 1989) and producing more work to generate new or fresh perspectives over and over again (Jameson, 1984 p. ix). Lyotard observes:

"Postmodern science - by concerning itself with such things as undecidables, the limits of precise control, conflicts characterised by incomplete information, "fracta", catastrophes and pragmatic paradoxes - is theorising its own evolution as discontinuous, catastrophic, nonrectifiable, and paradoxical." (p. 60)

However, Lyotard (p. 65) quickly cautions that social discourse is not governed by simple scientific pragmatics. He describes postmodern discourse as a monster formed by the interweaving of heteromorphous language games, that are no longer legitimated by a single traditional/modern metanarrative. The absence of a metanarrative, however, has been compensated by the rise of the criterion of performativity. Thus, it can be argued that a paralogical approach to social pragmatics would entail exposing the dominance of the performativity criterion and then a continuous attempt to generate new perspectives, the point of which would be not to reach any consensus. Scholars such as Nola \& Irzik (2003, p. 419) observe that paralogical activity is based on dissensus, heterogeneity and plurality rather than homogeneity and universality - the premise being that new knowledge comes into existence by challenging the status quo (Czarniawska, 2001).

For Lyotard (p. 60), the petit récit or the little narrative is the quintessential form of paralogical reasoning. Unlike scientific knowledge, governed by the need for legitimation, narratives or stories are rooted in local determinism i.e. they do not seek legitimation in a metaprescriptive. They are defined and evaluated according to the criteria set by the society in which they are shared. The narrative form is also much more plurivocal, encompassing multiple perspectives. 
In addition to the main storyline, popular stories are often peppered with descriptions of the state of the sky, flora and fauna, ethical dilemmas relating to children, friendship, neighbours, foreigners, interrogative statements, and evaluative statements. Thus, in contrast to scientific knowledge, narrative knowledge does not prioritise its own legitimation and avoids being defined by the reigning metanarrative. Scholars such as Hokowhitu (2009) and Hokowhitu \& Page (2011) observe that Māori tribal histories are akin to petit récits since they never claim to be universal truths. Unlike colonial historians driven by the search for a singular truth, the variability of the narratives between different tribal groups is accepted. This element of local determinism of a little narrative is arguably what makes scholars such as Eagar \& Dann (2016) describe even a selfie as a petit récit, narrating an individual's human brand in the virtual sphere.

Scholars drawing upon the Postmodern Condition have however mostly employed the tenet of 'performativity' in their studies. Gond et al. (2016) observe that the concept has been mainly used to critique the reconstitution of academe along performative lines (Cowen, 1996), be it an emphasis on pedagogical approaches that develop workplace oriented skills (Kalfa \& Taska, 2017), or the advent of a corporate culture in education (Ball, 1998), where academic boards are more keen on complying with efficiency audits than providing academic quality assurance (Rowlands, 2012). For Fournier \& Grey (2000, p. 17) this entails defining knowledge in terms of a 'means-ends calculation'. The authors further argue that critical management studies actively question the subordination of knowledge to the criterion of efficiency i.e. it has an anti-performative stance that endorses the Lyotardian view of knowledge being a product of dissensus (Czarniawska, 2001). For instance, Case \& Piñeiro (2006) examine the villainous portrayal of project managers by programmers for the former's limited appreciation of the aesthetics of coding and their preoccupation with producing functional applications alone, within budget. Similarly, Garrick \& Chan (2017) argue that attempts to codify tacit knowledge held by professionals to increase its efficiency, do not understand the personal nature of such knowledge, given the challenges of the workplace.

The above scholarly works demonstrate how a preoccupation with the performative results in a narrowing of focus, reducing institutions to calculative constructs where anything that is not efficient risks marginalisation. However, according to Cooper \& Burrell (1988, p 96), performativity "takes precedence over thought itself..." i.e. for the decision maker, legitimising organisational activity in terms of the input/output ratio alone, becomes second nature. There is limited reflection on the nature and consequences of such decisions, most importantly, on the aspects that are marginalised. Paparone (2017) examines how performativity underpins US military doctrine and forms the basis of all US military action. The author presents a series of petit récits to provide a paralogical critique of the doctrine and showcase its fallacies and goes on to argue that a constant preoccupation with the input/output ratio results in a loss of moral reasoning. "The US military institution also exercises little or no reflexivity about some ethical 
dilemmas that its doctrine presents, perhaps creating irresolvable situations..." (Paparone 2017, p. 524).

While our paper adds to the above genre of critical studies, we contribute by illustrating how the criterion of performativity is actualised through accounting constructs. Although Lyotard's (1984) work has a widespread international audience, very few scholars have studied the nexus between the calculus of accounting and performativity. In this paper, we carry out a paralogical evaluation of financial reporting after an industrial disaster, a scenario largely underrepresented in the accounting literature, contesting the claims of safety and responsibility advocated therein. We draw upon internal correspondence, legal proceedings, scholarly research and interviews with former employees and victims to generate a petit récit that offers multiple but conflicting insights into the machinations of tragedy. Our little narrative is based on dissensus and is incomplete. It illustrates how a performative intent, actualised through accounting constructs, engineered the construction of an oversized pesticide plant in an emerging economy, led to possible compromises in maintenance, training and safety while marginalising any ethical and moral considerations, finally causing catastrophe.

\section{Method}

The data for our paper were derived from two sources. We started with document analysis of the annual reports of the Union Carbide Corporation (UCC) and Union Carbide India Limited (UCIL) for the year ended 31 December 1984, the year of the tragedy. According to Hopwood (1996), annual reports are instrumental to the construction of specific visibility and meaning. In a similar vein, Preston, Wright \& Young (1996, p. 114) observe that annual reports serve as a medium of transmitting 'a' particular message. Corporations use annual reports not only for representational purposes but also for constitutional purposes (p. 115). Our approach toward examining the annual reports can be described as what Lyotard calls, postmodern. He observes that a postmodern approach "...denies the solace of good forms, the consensus of a taste ... [and] searches for new presentations...to impart a stronger sense of the unpresentable" (p. 81). In other words, we follow in the footsteps of critical accounting researchers examining various other disaster situations (Cooper et al., 2011; Siddiqui \& Uddin, 2016) to question the state of "order" in the annual report, i.e. the facade of stability and responsibility in the aftermath of disaster, in an attempt to reach out to the marginalised perspectives.

To challenge the status quo of post-disaster annual reports, we drew upon supporting documents $^{2}$ used in the long and protracted litigation around the disaster. We examined in

\footnotetext{
${ }^{2}$ Most of the documents examined for the purposes of this study were located at the Sambhavna Trust Library in Bhopal. The Trust is the largest non-governmental organisation in the city, dedicated to the improvement of
} 
particular those documents that used accounting constructs in their narratives to legitimise courses of action in relation to the Bhopal plant, endorsing the notion of performativity/efficiency. Such constructs included cost-volume-profit analysis, ratio analysis, cash flow analysis, budgets and capital investment appraisals. While some documents were in the form of telex messages and letters exchanged between senior company executives, others were in the form of reports/appraisals, used at various internal meetings to evaluate the future of the Bhopal plant, employee testimony and press coverage (see table 1 in the appendix). The period under consideration was from 02 December 1973, when the first capital budget proposal for constructing a pesticide plant in Bhopal was placed before the UCC Management Committee for approval to 31 December 1984, i.e. the end of the financial year 1984.

Our second source of data was semi-structured interviews with victims of the disaster. In August 2018, we interviewed ${ }^{3} 13$ individuals affected by the tragedy, in Bhopal. Out of the 13, 5 were former employees of the Bhopal plant while the remainder were chosen with the help of Sambhavna Trust staff members. The interviews lasted between 20 minutes to an hour and were all conducted in Hindi (the local language). We invited the interviewees to recount their experiences of the night of the tragedy and its immediate aftermath to gain an insight into the events as they unfolded that night. We asked the former employees to comment on what they thought had caused the tragedy. We drew to their attention some of the internal correspondence between UCC and UCIL officials and asked them to reflect on the incidence of a cost minimisation/profit maximisation culture at the plant and if such a culture did indeed exist, its manifestations in daily plant life. While the former employees were very reluctant to be recorded on tape, others were happy for the interviews to be recorded. So, during our conversations with the former, with consent, we made notes on important issues. At the end of each session, we presented a summary of our notes to the interviewee for his/her approval, prior to use in our study.

The objective of carrying out the interviews was two-fold. First, as suggested earlier, a petit récit according to Lyotard encompasses conflicting multiple perspectives. So, we wanted to go beyond the aforementioned examination of reports and internal correspondence to include other viewpoints that would promote dissensus and heterogeneity in the narrative. Second, for Lyotard (1984, p.81), a postmodern approach entails showcasing the unpresentable in presentation itself. While it is impossible to capture the extent of the tragedy on December 3, 1984 in words, we want to move the reader to as close an appreciation as possible of the

the health and well-being of the victims of the tragedy. We contacted the Trust through the Bhopal Medical Appeal Health Fund in the UK and were granted access to the Trust's library.

\footnotetext{
${ }^{3}$ Prior to the interviews, we assured the interviewees that their anonymity and confidentiality would be preserved, and their views/statements would be used for academic purposes only. Given the sensitive nature of the study, no personal questions were asked at any time during the interviews.
} 
terroristic consequences of performativity. The task for the postmodern scholar, according to Lyotard (p.81) is to provide allusions to that which can be conceived but cannot be presented.

To showcase the incidence of performativity, as suggested by Lyotard (1984), we identified three themes for our data analysis - plant formation, plant performance and plant safety. The rationale behind these three themes was an intention to produce a little narrative that would provide alternative interpretations of the beginning, the functioning and the catastrophic ending of the Bhopal pesticide plant. We turn now to our case and case analysis. We begin with a discussion of the disaster and then present a petit récit that showcases the incidence of performativity in the discourse around the Bhopal plant and in the process provides multiple perspectives on the disaster.

\section{The 1984 Bhopal Gas Tragedy}

On December 3, 1984, a highly toxic cloud of methyl isocyanate (MIC) leaked from a pesticide plant in Bhopal, the capital city of the state of Madhya Pradesh in India. The pesticide plant was owned by Union Carbide India Limited (UCIL), a majority-owned subsidiary of the US multinational, Union Carbide Corporation (UCC). The leak was the consequence of a large volume of water entering a tank storing 40 tons of methyl isocyanate, around 9:30pm, the day before. This triggered a chemical reaction resulting in a tremendous increase of temperature and pressure in the tank. Around 12:30am, 27 tons of MIC along with hydrogen cyanide and other reaction products exploded into the night air of Bhopal. Of the 800,000 people living in Bhopal at that time, no one knows exactly how many people died that night. While official estimates such as those by the UCC and the Indian Government range between $1800-4000$, unofficial estimates such as those by non-governmental institutions and academics range between $7000-10000$. At the time of writing this paper, 573,588 have received compensation claims and are therefore officially recognised as victims.

According to Eckerman (2005, p. 99) barely two weeks after the exposure, there was a jaundice epidemic in Bhopal, which according to medical experts was chemically induced. Reported delayed effects also included intestinal bleeding, pain in the kidneys, general debility. Nine cases of partial paralysis were reported at the local Hamidia hospital. The damage to the lungs was most widespread. A December - January 1985 survey of the most badly affected slums revealed that of the 1152 slum-dwellers who had worked prior to the disaster, 881 i.e. over $75 \%$ were incapacitated and unable to return to work (Bang, 1985, p. 36). However, scholars such as Lapierre \& Moro (2003), Murthy (2014) observe that the psychological consequences of the tragedy, though difficult to measure, were just as severe. Victims reported panic syndromes that drove them to a state of absolute anxiety, depression, impotence and anorexia. Many were driven to despair and committed suicide. However, women were the worst affected by the tragedy. A report published by the Indian Council of Medical Research on the results of a 1985 epidemiological study of 2566 pregnant women exposed to the gas, showed 373 abortions and 82 stillbirths (ICMR, 2004, p. 9). According to Shrivastava (1987, p.3), family 
life was also dramatically affected as women and children with little or no idea of life outside home had to look for means of earning a livelihood.

Although the Union Carbide Corporation (UCC) immediately tried to absolve itself of legal responsibility for the disaster by arguing that the gas leak could only have been caused by deliberate sabotage, the company accepted moral responsibility for the tragedy. After four years of intense legal wrangling, which included the court case being moved to India from the US, an out of court settlement for $\$ 470$ million was reached between the UCC and the Indian Government on February 14, 1989. This translated into $93 \%$ of the survivors being paid Rs. 25,000 (approx \$500). In 2002-03, this amount was paid a second time out of the interest that had accrued on undistributed funds held by the Government. The compensation was relatively small given the underestimation of the long-term health consequences ${ }^{4}$ of exposure to the lethal gas and have been a cause of considerable unrest among the victims ever since.

Thirty-five years have passed since the gas explosion, but the Bhopal saga is far from over (Jain, 2019; Mishra, 2019). We visited the plant site and found an abandoned, foul-smelling junkyard, full of rusted iron pipes and storage tanks and toxic waste strewn around. The laboratory had hundreds of chemical bottles, some empty and others half empty, some arranged on shelves, others rolling on the floor with substances oozing out of them. We were told by local NGO workers and slum-dwellers that toxins from the decaying toxic waste were being washed by the monsoon rains into the groundwater. Relatedly, the inner seals of the pits (used to dump toxic waste) on the factory premises, had broken and the left-over toxic waste was being washed into the soil, contaminating the local groundwater reserves. A study carried out by the UK based Bhopal Medical Appeal (BMA) found chemicals in drinking water, 2400 times the World Health Organisation guidelines (Ramesh, 2009). This has affected a completely new generation of people, who came to Bhopal in the mid-late 1990s looking for work. In June 2019, it was reported that 48 separate housing colonies around the factory, housing over 100,000 people were affected by contaminated groundwater (Sambhavna, Water Contamination, 2019).

The Central and State Governments continue to prevaricate when questioned about cleaning up the plant site (PTI, 2012). Although the Supreme Court of India had ordered the State

\footnotetext{
${ }^{4}$ These include ocular and respiratory illnesses, gynaecological issues along with high levels of reproductive disorders, and neurological and neuromuscular effects. Immunological impacts have led to diseases such as tuberculosis manifesting at three times the national average. Anxiety, memory loss and depression are regularly observed psychiatric effects. Evidence of second generational effects is now firmly established: some boys born to gas-affected parents suffer growth retardation, whereas hormonal chaos has afflicted girls.
} 
Government in 2012 to issue tenders for cleaning up the site, to date none have been issued (Dutta, 2017). The UCC was acquired as a fully owned subsidiary of The DOW Chemical Company (TDCC) in 2001. The latter has refused to entertain any commitments in relation to the Bhopal tragedy on the grounds that the UCC and the TDCC did not merge. Although UCC stock is fully owned by the TDCC, the company argues that the UCC, as a TDCC subsidiary, continues to exist as a separate company with its own assets and liabilities. Several petitions and lawsuits have been filed against DOW and the UCC in Indian courts for cleaning up Bhopal and for the payment of adequate compensation. However, matters have become complicated since the August 2017 merger between Dow Chemical and DuPont and subsequently the April 2019 trifurcation of DowDuPont into three publicly traded companies, namely, Dow Inc., DuPont Inc. and Corteva Inc., resulting in a redistribution of UCC assets and liabilities, in particular those aligned with its specialty products business. As such, the Bhopalis carry on their campaigns for just compensation (Varma, 2013; Francis, 2014; PTI, 2016; Alavi, 2017; "Bhopal disaster 35 years on", 2019), for social and economic rehabilitation ("Gas victims demand CBI probe", 2014; Ayub, 2013; Gupta, 2013; PTI, 2017), for clean water (Singh, 2012; Vaidyanathan, 2012; "Provide clean drinking water", 2015) and as we observed during our interviews, for the plant site to be cleaned up.

The chronicle of Bhopal presented in this section is not intended to be a full account. Rather it serves as a short summary of the important aspects of the tragedy. Research on the Bhopal Gas Disaster has focused primarily on three areas. First, the medical dimension, that has studied the immediate and long-term health effects of the tragedy (e.g., De, 2012; Malla, Senthilkumar, Sharma \& Ganesh, 2011; Mishra, Dabadghao, Modi, Desikan, Jain \& Mittra, 2009; Sriramachari, 2005; Dhara \& Dhara 2001; Dhara \& Kriebel, 1993; Raizada \& Dwivedi 1987). Second, the legal dimension, where scholars have examined the nature and role of advocacy after the crisis from various perspectives such as adequacy of compensation, multinational liability, corporate responsibility and human rights law (e.g., Paul \& Baxi 2015; Fortun, 2009; Zavestoski, 2009; Fletcher, Ono, \& Roy, 2005; Cassels, 1993; Trotter, Day, \& Love, 1989; Galanter, 1986; Abraham \& Abraham 1991). Thirdly, scholars have also studied the changes in public policy after Bhopal, in particular the impact on crisis management, sustainable development and attitudes toward chemical companies (e.g., Iyengar \& Bajaj, 2011; Belke \& Dietrich, 2005; Jasanoff, 1994; Reich \& Bowonder, 1992; Bowman \& Kunreuther, 1988). A number of books chronicling the events that led to the tragedy and its aftermath have also been published overtime (e.g., Lapierre \& Moro, 2003; D'Silva, 2006; Eckerman, 2005; Shrivastava 1987, 2011; Hazarika, 1987; Everest, 1986).

In the domain of organisation studies, however, relatively few scholars have focused on the Bhopal Gas Tragedy. Notable contributions include those by Weick $(1988,2010)$ on enacted sensemaking in crisis scenarios where the author examines how an enacted perspective can shed understanding on individual actions contributing to a crisis and at the same time, how such actions can also manage the severity of crisis. Scholars such as Matilal \& Höpfl (2009), 
Ice (1991) and Marcus \& Goodman $(1989 ; 1991)$ examine the implications of communicating the tragedy to an external audience. Unlike Marcus \& Goodman (1991) who discuss the tensions between accommodating victims and shareholders in post disaster corporate policy, Ice (1991) explores the various rhetorical strategies employed by the UCC in communicating and repairing its relations with all stakeholders including customers, employees and the government. However, few studies have examined the role of accounting in the making of this disaster. It is this gap in the literature that this study intends to fill.

With this in focus, we now move on to the analytical strands of our paper. This is organised into 4 sections. First, we examine the 1984 annual reports of the Union Carbide Corporation (UCC) and Union Carbide India Limited (UCIL), issued in the aftermath of the disaster. We then start constructing a petit récit employing Lyotard's (1984) idea of paralogical reasoning. As is always the case with a story, our little narrative on Bhopal also has a beginning, a middle and an end. We start by examining how an oversized plant was built in Bhopal and then go on to discuss the manifestations and implications of the various cost-cuts in daily plant life. Finally, we look at the terroristic consequences of an obsession with performativity on December 3, 1984.

\section{The 1984 Annual Reports}

\section{The Union Carbide Corporation}

The 1984 Annual Report begins with a description of how the UCC was one of the largest multinationals in the world, with consolidated sales of $\$ 9.5$ billion, and with 104,000 stockholders owning 70 million shares. This is followed by a 'Letter to the Stockholders' from the Chairman, Warren Anderson and the President, Alec Flamm. According to the letter, 1984 began well for the multinational with two strong first quarters, with a relatively lacklustre performance in the latter two quarters owing to a sluggish economy and a strong dollar.

A few short paragraphs follow, focussing on the Bhopal tragedy. Shareholders are informed that the catastrophic consequences of Bhopal 'stunned' the company. "...[C]arbiders, everywhere, found it difficult to believe that their company was the one in the headlines" (UCC 1985 , p. 2). However, the company swiftly made arrangements for providing emergency relief to the victims and proceeded to deal with various issues related to the tragedy. Stockholders are advised that any compensation payable in relation to Bhopal was not going to have a material adverse effect on the company's finances and that only a small fraction of the UCC business has been affected by the incident. A small group of executives had been placed in charge of managing the Bhopal situation so that the rest of the business could carry on as usual. Stockholders are also informed that total sales were $\$ 9.5$ billion - an increase of $6 \%$ compared 
to 1984 . Net income increased from $\$ 79$ million in 1983 to $\$ 323$ million in 1984. As a consequence of the Bhopal tragedy however, an extraordinary charge of $\$ 18$ million against the yearly profits reduced earnings per share from $\$ 4.84$ to $\$ 4.59$.

The rest of the letter focuses on the other segments of the company such as the underperforming Petrochemicals and Metal \& Carbon Products segments. Investment in these segments, as per the letter, would be limited and any cash generated from these segments would be redeployed in the Industrial Gases, Consumer Products, and Technology, Services and Specialty Products segments, all of which performed well. Stockholders are also informed of promising future developments in China, commercial success with 12 new high-performance specialty products, completion of construction of the largest polysilicon plant in the US and good progress on a joint venture with the Shell Chemical Company for the development of polypropylene. The letter also states that the long-term business strategy of the company was to increase the share of earnings from technology-intensive businesses and in keeping with such a strategy, the company had acquired Katalistiks International, B.V. and finalised the sale of its welding and cutting business in the United States.

The letter concludes with an acknowledgement of the negative publicity the company received in the wake of the Bhopal crisis. However, stockholders are assured that the company would make positive use of the media attention to lead a re-examination of issues relating to public policy and the chemical industry.

The 1984 UCC Annual Report then presents an essay 'After Bhopal' evaluating the relationship between the chemical industry and society.

\section{After Bhopal}

The essay, addressed to the general members of the public, begins once again with an expression of shock over Bhopal and a reiteration of a "quick and compassionate" response by the UCC to the tragedy. The company's position on compensation is also stated: “...a quick and fair settlement of the claims of all victims would serve their needs far better than prolonged and expensive litigation" (UCC 1985, p. 4). This is followed by a discussion on the need for reconsideration of the regulations and policies affecting the chemical industry, particularly in relation to safety.

Readers are informed about the positive contributions of the chemical industry to society, such as the creation of large scale job opportunities and significant contributions to national income 
and to developing economies such as India where the Green Revolution that saved $10 \%$ of the annual food crop and fed an additional 70 million people, would not have been possible were it not for pesticides and western technology. As such multinational companies, their capital and their technology are crucial for developing economies for hunger and poverty alleviation.

A significant chunk of the essay is devoted to proclamations of safety. Readers are told that after Bhopal the UCC had initiated a worldwide risk assessment study to ensure safety standards were being followed at all facilities run by the multinational, ensuring the protection of both the local residents and employees. Discussions were going on in the chemical industry regarding "early warning and preparedness programmes", sharing knowledge of chemicals being manufactured and associated risks with communities that live close to chemical plants and a nationwide hazard communications system for evaluating the risks associated with the operations of a chemical plant and the necessary safety mechanisms to minimise such risks. Safety considerations relating to the transportation of hazardous chemicals are also examined. Readers are informed that two countries (not named in the report) had refused to accept shipments of methyl isocyanate after Bhopal. The letter stresses that transportation safety was one of the pivotal concerns of the chemical industry which had invested millions of dollars in the US in particular, in safe transportation technologies.

In relation to Bhopal, the essay states that UCIL managers were evaluated by the UCC and were well-qualified for their positions. Senior management, in particular had an excellent track record. Nevertheless, it had been argued that the cultural and educational background of developing countries might not be able to support the operations of sophisticated Western technologies. Moreover, developing countries sometimes imposed restrictions with regard to construction of facilities using local resources only or employment of nationals of the developing country alone.

The essay ends hoping that although lessons will be learned from Bhopal regarding the safety policies and practices of the chemical industry, it will not affect the international transfer of technology.

The rest of the 1984 UCC Annual Report says very little about the Bhopal Gas Tragedy. In the pages that follow the above essay, the company provides a review of its various segments e.g. petrochemicals, industrial gases, metals and carbon products, consumer products and finally Technology, Service \& Specialty Products, of which the Bhopal plant was a part of. Here, readers are told that the success of the segment for 1985 would very much depend on the recommencement of the production of methyl isocyanate (MIC) since it was a key ingredient of the pesticides manufactured by the company. Production of the chemical at the US plant in West Virginia had been suspended indefinitely following the explosion of the MIC tanks in 
Bhopal. Production would commence only after an internal report on Bhopal was available and the likeliness of such an accident at the West Virginia plant had been assessed. The segment reviews are followed by geographical reviews of Africa \& Middle East, Canada, Latin America and the Far East, where readers are informed that following the catastrophe, the Government of India had closed the Bhopal plant.

The remaining sections of the report focuses on an analysis of comparative financial data. Readers are informed that the 1984 net income of $\$ 323$ million, after taking into consideration the extraordinary charge of $\$ 18$ million related to Bhopal, represented an increase of $309 \%$ over that in 1983. The higher profit of 1984 is mainly driven by an increase in net sales by over \$500 million, compared to that in 1983. However, excluding the extraordinary charge of 1984 and a non-recurring charge of \$241 million (\$139 million after tax, \$1.98 per share) in 1983 relating to the permanent closure of petrochemical facilities on the Gulf Coast, net income in 1984 was 56\% higher than that in 1983. Net income in 1983 (once again, excluding the nonrecurring charge) was 30\% lower than that of 1982, which was 52\% lower than that in 1981. The extraordinary charge of $\$ 18$ million in 1984 translated to $\$ 0.25$ per share and was concerned with operational expenses incurred and anticipated in connection with the tragedy. Relatedly, in comparison to 1983, an increase in the 1984 sales by $6 \%$ and corresponding cost of sales by $2 \%$, has resulted in the highest gross margin ratio since 1977 . The review also states that from the beginning of 1984 to the Bhopal tragedy of December 3, the market price of a UCC share ranged from $93 \%$ to $69 \%$ of its book value on 31 December 1983 of $\$ 69.95$.

Notes to the accounts on commitments and contingencies suggest that numerous lawsuits had been filed against the UCC/UCIL in district and state courts in the United States and in India on counts of injuries and deaths from the gas exposure in Bhopal. These lawsuits sought compensation either of an unspecified amount or varying amounts running up to billions of dollars. Additionally, three stockholder derivative actions and four class actions on behalf of the purchasers of the Corporation's securities had been filed in the US District Courts in relation to the Bhopal accident. These lawsuits accused the officers and directors of the UCC of mismanagement, gross negligence and breach of fiduciary duties for not disclosing as well as not being able to remedy the deficiencies in the Bhopal and West Virginia plants as a consequence of which the Corporation was faced with huge liabilities resulting in a drop in the Corporation's stock price. The lawsuits claim unspecified damages for shares purchased between 1981 - 1984. The note on commitments and contingencies ends with the management reassuring shareholders that the outcome of the lawsuits, though impossible to predict would not adversely affect the financial position of the Corporation.

The auditors observe that the consolidated financial statements comply with generally accepted accounting principles and present the financial position of the UCC and its subsidiaries, fairly. 
However, the reader is reminded that numerous lawsuits have been filed against the UCC and/or its 50.9\% owned subsidiary, UCIL, in relation to the Bhopal Gas Tragedy.

\section{Union Carbide India Limited}

The Annual Report begins with the Directors' Report where the latter express their regret for an "...unprecedented accident in the Company's pesticides plant" (Union Carbide India Limited 1985, p. 1). The report further states that although the exact cause of the accident was unknown, ".... in all probability, some quantity of water found its way into Tank 610 inspite of the prescribed precautions or by an unauthorised, deliberate or inadvertent act of someone. This led to an unprecedented, unanticipated and uncontrollable runaway chemical reaction in the tank, resulting in the escape of methyl isocyanate into the atmosphere" (UCIL 1985, p. 1). Shareholders were also informed that unusual weather conditions prevailing that night also contributed to the accident and that "when the factory was put up, it was considerably away from the then populated outskirts of Bhopal in area exclusively earmarked for industrial development" (UCIL 1985, p. 1). The Directors also elaborate that the Bhopal factory was subject to periodic inspections under the Factories Act, Insecticides Act and the State Pollution Control Board and that at no point of time had any noticeable fault been found with the various safety systems. Trained and qualified operators had always operated the Plant.

Immediately after the accident, according to the Report, the UCC announced a contribution of \$1 million to the Prime Minister's Relief Fund and UCIL offered Rupees 1 crore to the Chief Minister's Relief Fund. Both the offers were made unconditionally but the State Government rejected UCIL's offer. Shareholders were further informed that on February 20, the President of India promulgated an Ordinance called the 'Bhopal Gas Disaster (Processing of Claims) Ordinance 1985', subsequently made an Act of Parliament, under which the Government of India appointed itself as the sole representative of the victims and filed a suit against the UCC in the District Court of the Southern District of New York. Hundreds of compensation related cases had also been filed in the state courts. According to the Directors, “... an out-of-court settlement would be the best method of providing speedy relief to the victims and would be in the best interest of all concerned" (UCIL 1985, p. 2).

The Report informs the shareholders that under orders of the State Government, the Bhopal Plant remained closed since December 3, 1984. The Government had refused to renew the licence of the factory under the Factories Act, 1948. As a consequence, the Board had decided to close the Bhopal Plant with effect from July 11, 1985. The closure of the Plant in the opinion of the Directors would affect the future financial position of UCIL. The Report ends with the Directors not recommending any dividend for the year ended 1984. 
The Director's Report is followed by numerical charts and graphs showing distribution of revenue for 1984, share distribution, 10 years financial highlights. The Profit \& Loss Account for the year ended December 25, 1984 reflects items such as Total Sales - Rupees 2,228,977,000, Materials Consumed - Rupees 991,601,000, Depreciation- Rupees 50,112,000, Excise Duty - Rupees 340,309,000 etc; the Balance Sheet as at December 25, 1984 shows Goodwill at cost - Rupees 3,000,000, Fixed Assets - Rupees 441,859,000, Cash and Bank balances - Rupees 53,888,000, Share Capital - Rupees 325,830,000 etc. The Notes to Accounts state that the Bhopal plant remained closed since December 3, 1984 and that the State Government had refused to renew the factory's licence. However, closure had not resulted in the movement of any assets. The Plant was being maintained to avoid any further deterioration. As such, writing-off the assets at the Bhopal plant was not being considered.

The Auditors state that subject to the legal consequences of the Bhopal Gas Tragedy, the accounts give a true and fair view of the state of the company's affairs as at December 25, 1984.

\section{A Paralogical Evaluation}

This section produces a petit récit on the Bhopal Gas Tragedy. In the spirit of Lyotard's (1984) emphasis on local determinism, the storyline of our little narrative is rooted in the operations of the pesticide factory in Bhopal and all the sources of information in our story are also directly connected with the Bhopal plant. The purpose of this section is two-fold. First, we showcase the obsession with performativity in the formation, running and discontinuation of the Bhopal plant. Second, in an attempt to seek dissensus and heterogeneity, our little narrative includes multiple perspectives on the tragedy such as those of the former employees and the survivors.

\section{Plant formation}

We begin our evaluation by briefly looking at the history of the construction of the Bhopal plant. In 1970, Edward A. Munoz, the general manager of UCIL submitted a proposal to the Licensing \& Progress Section of the Industrial Development Internal Trade and Company Affairs of India seeking permission for the manufacturing of up to 2,000 tonnes of methyl isocyanate and 5,000 tonnes MIC-based agricultural pesticides and formulations. However, to ward off any competition from the likes of Bayer and the Food Machinery Corporation from India's lucrative pesticides market, the UCC decided to construct a plant that had the capacity to manufacture 10,000 tons of pesticides. In an interview to the Environment Business Bureau, in December 1994, Edward Munoz observed: 
"We were cornering the market you see, by asking for 10,000 tons. We knew that 10,000 tons was a--something far into the future-- wasn't realistic for the next five to ten years. But we knew that if we asked for 2 million pounds and then Bayer will ask for other 2 million pounds, and FMC will come and ask for--and then we have competition in the market, so we ask for 10 million pounds." (Karliner, 1994)

A similar observation was made by one of our interviewees, a former employee of UCIL stationed at the Bhopal plant.

Before you design a plant, you need to carry out market research to identify the size of the market. How much can we sell? What will be the total demand for our products? The research was carried out, but the higher authorities, I do not want to take any names, completely disregarded the market research and approved the design of an oversized plant for their benefit. For example, if the capacity required was 4 tons, they built a plant with a capacity of 10 tons. So, production was always in excess of demand.

The problem with building such a big plant was also the fact that it would warrant the storage of a large quantity of methyl isocyanate on site. According to Munoz (Karliner, 1994), this was a "crazy" proposition as the MIC was a very unstable chemical which reacts with heat very quickly to attain an explosive nature, which can only be controlled up to a certain point. The South Charleston Institute of the Union Carbide Corporation which had a similar pesticides plant and where the Bhopal plant was designed, was aware of Munoz's aversion to construction of a large MIC storage tank and his preference for storing small amounts of MIC using 55 gallon drums which did not pose a threat - any explosions could be easily contained to the factory. Nevertheless, a big MIC storage tank was constructed in Bhopal. When questioned by Karliner (1994) about the logic behind the UCC engineers "loving" the idea of a big tank, Edward Munoz responded as follows:

"Well, look, one part of the thing is that we did have a big tank in Charleston, so we need [a] big tank in anywhere else. You know, what's good for Peoria is good for Bhopal and etc., etc. I mean why is, that would be one philosophy, the other is that [in] an engineering department engineers the project manager, etc. [e]verybody's salary is based on the amount of money they spend.... the more money you have to spend, the more people you have reporting to you, etc., the bigger your salary. And part of that is that Charleston loves big projects. The bigger the better." (Karliner, 1994) 
In the interview, Munoz further argued that while it made sense for the UCC to store the large amounts on site since it was reselling the MIC to companies such DuPont and FMC, there was no such business arrangements in India. The chemical was to be used entirely on-site to manufacture pesticides.

Lapierre \& Moro (2003, p. 95) suggest that the UCC's design of the Bhopal plant was based on Edward N. Hay's point system for evaluating every job done in a company. Developed in the 1960s, under the system the more complex a job, the higher the number of points; each point corresponding to a salary advantage. The UCC was a devout follower of Hay's point-based system and it was in the interests of the engineers assigned to planning and implementing any industrial project to see that, right from the outset, it was given the maximum number of points possible because that would mean higher salaries for all.

Arguably, the more complex the job, the more technological sophistication would be required in its design. For Lyotard (1984), as suggested earlier, the increased use of technology is ultimately rooted in the desire for increasing performativity. Thus, a big plant with a big tank and complex technology would always be perceived as a more efficient design and as one that would provide higher returns on investment in the future than a small tank. The idea of a big tank therefore did not meet any disapproval from the UCC Management Committee and despite Munoz's warnings that the demand for pesticides will never exceed 2000 tonnes in India, a plant capable of manufacturing 10,000 tonnes with a huge tank was built in Bhopal. As discussed earlier, Lyotard (1984) also observes that the notion of performativity as the ideal input/output ratio, is predicated on an assumption of stability of the system where all the variables are thought to be known in advance. In relation to the Bhopal plant, such an assumption is echoed by Munoz, when asked by Karliner (1994) if the UCC had thought about safety when including a big tank in the plant design in Bhopal.

'Well, they felt that they knew they could control the MIC, that they knew all about it...And whether we know how to control it or not but to put it in an urban setting is a little, have little regard for the safety of the rest of the people. What can happen will happen eventually, and they were oblivious to that problem."

In sum, for the UCC designers, a big plant i.e. big inputs would unquestionably lead to big outputs and high returns for all. The chances of an aberration did not arise since all the various scenarios involving a substance as volatile as MIC were presumed to be known. Such was the dominance of the performativity criterion that right from the very beginning, safety had taken a back seat. 
It is worth emphasising that both the design and the technology used in the Bhopal plant were supplied by the UCC. A similar legitimation exercise, based on accounting constructs such as anticipated return on investment, can be observed in the MIC plant proposal by UCIL sent to the UCC Management Committee on December 2, 1973. Statistics are provided at the beginning of the proposal estimating the future performance: "Probable OCF Return 12\%, Probable Average ROI (Before Tax) 25\%." The proposal also states that no direct equity contribution will be required from the UCC in financing the plant. An examination of the MIC plant proposal further suggests the adoption of unproven, untested technology on the basis of an accounting rationale. The "I-Naphthol Process" required to manufacture alpha-naphthol, a key ingredient of pesticides was locally developed by UCIL since the UCC process required special construction materials, complex technical know-how and was more suited to large scale production. The UCIL process was simpler to operate and needed fewer complex construction materials. The MIC plant proposal then provides a comparative analysis of these two processes based on a transfer price of $\$ 62.70 / \mathrm{lb}$, reproduced below:

\begin{tabular}{|c|c|c|}
\hline & $\begin{array}{r}\text { UCC } \\
\text { Process }\end{array}$ & $\begin{array}{r}\text { UCIL } \\
\text { Process }\end{array}$ \\
\hline & $\${ }^{\prime} 000$ & $\$ \$ 000$ \\
\hline Investment & 113.0 & 54.0 \\
\hline Transfer price & 62.7 & 62.7 \\
\hline $\begin{array}{l}\text { Period } \\
\text { Expense }\end{array}$ & 4.4 & 2.0 \\
\hline Raw Material & 29.8 & 43.3 \\
\hline Other Costs & 2.7 & 4.2 \\
\hline Total Plant Cost & 36.9 & 50.4 \\
\hline Depreciation & 9.0 & 4.3 \\
\hline ROII & 16.8 & 8.0 \\
\hline$\%$ ROI & 14.8 & 14.8 \\
\hline
\end{tabular}


Since both the processes have an identical ROI, the proposal argues that the UCIL process fares better than the UCC process since the cost of investment is lower. However, the report goes on to state categorically:

\begin{abstract}
"The comparative risk of poor performance and of consequent need for further investment to correct it is considerably higher in the UCIL operation than it would be had proven technology been followed throughout. CO and I-Naphthol processes have not been tried commercially.... In short, it can be expected that there will be interruptions in operations and delays in reaching capacity or product quality that might have been avoided by adoption of proven technology. UCIL finds the business risk in the proposed mode of operation acceptable, however, in view of the desired long-term objectives of minimum capital and foreign exchange expenditures. UCC concurs." (Union Carbide Eastern [UCE], p. 12)
\end{abstract}

For Lyotard (1984), as suggested earlier, performativity is defined as efficiency measured according to the best input-output ratio (p.46). In this case, using unproven UCIL technology kept capital investment down and provided the same return on investment that using the proven UCC technology would have provided. The criterion of performativity thereby legitimises the use of unproven technology in the Bhopal plant. In a similar vein, a former employee observed that to keep costs low, inferior quality materials were used in the construction of the plant:

If the required investment in the Bhopal plant was 100 rupees, it was constructed at 20 rupees. The materials used to construct the pipelines were all B-grade. Instead of glasslined stainless-steel pipelines, as used at the UCC plant in Virginia, in Bhopal, carbon steel was used. MIC needs to be always stored at low temperature below zero as it is a lot less reactive when it is cold. Here, they provided a very cheap refrigeration system compared to the Virginia plant. The Bhopal plant had a direct chilling system just like the one in a normal fridge. Freon was used as a coolant, but Freon is highly reactive with MIC. In Virginia, however, they had a more expensive intermediate cooling system where they would first cool down chloroform and then use chloroform to cool MIC. Chloroform is a solvent used in the preparation of MIC so even if there was a leak, there would be no reaction.

Thus, the power of performativity, defined by accounting constructs, is so dominant that it does not allow issues such as safety and responsibility to enter the debate (or the language game in Lyotard's terms) causing what Guérard, Langley \& Seidl (2013) call a displacement from "reasoned justification" to a narrower "instrumental rationality". Accordingly, issues such as 
the Bhopal plant was being constructed in an urban area, MIC was a deadly chemical made from Phosgene and should not therefore be stored in large quantities on plant premises etc were all cast aside in the quest for the best input-output ratio.

We now turn to an examination of the operational performance of the Bhopal plant and show how the inefficiencies associated with an oversized factory created problems right from the very beginning.

\section{Plant performance}

An examination of UCIL financial statements suggest that the pesticide plant was far from being profitable. Total sales of pesticides for 1981 were Rupees 2213.59 lakhs, a $78 \%$ increase from the previous year. However, sales dropped to Rupees 1729 lakhs in 1983 and to Rupees 1399.43 lakhs in 1984 - a decrease of $21 \%$ and $37 \%$ respectively from 1981 . Though the plant had a capacity to manufacture 5000 tonnes, in 1982 only 2308 tonnes of MIC based pesticides were produced. This dropped further to 1647 tonnes in 1983 and to 1240 tonnes in 1984 . However, internal documents such as the "Review of the Capital Budget Proposal for the MIC based Agricultural Chemicals Project”, published in February 1977 by UCIL, suggest that abandonment of the project was already under consideration.

According to the Review, the original approved fixed investment was \$22.64 million, and the plant was expected to be operative in the third quarter of 1976. However, construction came to a standstill in the first quarter of 1976 owing to a liquidity crisis in UCIL's finances, depression in the agricultural market in 1975 resulting in stockpiles of the pesticides imported from the UCC and doubts about the market potential. By the latter half of 1976, it was realised that imported pesticides would cover $80 \%$ of the 1977 demand. To fulfil the remaining anticipated demand, project construction was restarted with a long-term loan of \$4.4 million from Indian financial institutions. The resulting cost escalation as well as additions to plant and equipment increased total project investment to $\$ 28.7$ million i.e. a $27 \%$ overrun. The review considered three options (a) abandonment of the project (b) restriction of the project to the apha-napthol and SEVIN carbamoylation units (c) completion of the project, and, recommended completion of the project as the future course of action. The recommendation was based on the loss of UCC equity of $51 \%$ and negative reactions of local stockholders when faced with the prospects of the realisation of minimal residual value from a project that had already spent $\$ 13.6$ million. The project was also expected to contribute to UCIL's bottom line in the 1980s. Net Income from Sales (NIFS) was predicted to be $\$ 14.5$ million in 1978 and projected to increase at an annual rate of $15 \%$ to $\$ 34$ million in 1984 . Gross margin of $7 \%$ in 1978 was expected to increase to $35 \%$ by 1984 due to higher volume and lower direct costs. Overheads at $13 \%$ of NIFS in 1978 would fall to $8 \%$ of NIFS by 1984 . R\&D expenditure would increase from $\$ 383$ 
million in 1976 to $\$ 880$ million in 1984 . Net Income after Tax (NIAT) was forecasted to be $\$ 412,000$ for 1980 and expected to increase to $\$ 3$ million in 1984. Return on Assets (ROA) would increase from $2 \%$ in 1980 to $15 \%$ by 1984 .

We can see in the above paragraph how accounting constructs conceptualise performativity, distinguishing between efficient and inefficient performance. It is also important to note here how the notion of performativity presumes complete knowledge of and total control over the functioning of a system, something that Lyotard (1984) dismisses as fiction since it is impossible to define all the variables constituting a system. We can also see how the choice of such variables is deeply influenced by the calculative logic of accounting. The decision to complete construction of the plant was based on accounting constructs such as forecasted increases in sales, gross profits, NIAT and decreases in direct costs and overheads, all predicated on the presupposition that the demand for pesticides market will follow a regular trajectory of growth at the rate of $15 \%$ per annum while costs would also follow a regular pattern of gradual decline between 1977 - 1984. This also meant that the plant builders had complete knowledge of the Indian pesticides market and had perfect control over the construction process and the running of the plant, both of which turned out to be otherwise.

A telex message addressed to R K Dutta, the then General Manager of UCIL and copied to R K Natarajan, the Director of the Agricultural Products Division of UCE, dated 03/04/1980 suggests that the plant was besieged with problems right from the very beginning:

“As you are aware MIC production has started at Bhopal plant from February 1980. During the period of last eight weeks operation, plant had three major shutdowns and experienced several technical problems which need to be resolved towards stabilising the plant at a desired efficiency. We strongly believe that Mr W J Woomer [an engineer at the UCC] who has number of years of experience in MIC plant running, will be the most suitable person to assist Bhopal at this critical time..." (Mody, 1980)

However, our interviews with the former employees of the plant suggest a different agenda behind these shutdowns. For example, one employee observed:

"Production always exceeded demand. As a result, the factory would never operate for the entire year. It would run for 3 months and then there would be a shutdown for 3 months. The employees were told that the shutdown was necessary for repairs and maintenance since hazardous chemicals were being used on site. They would say these things so that employee morale was not affected. Their main objective was to somehow 
stop production. Carrying out the repairs was secondary. But we started to see through these staged shutdowns very soon and stopped taking repairs and maintenance seriously. The same thing happened that night. When the water started leaking, the employees on duty reported it to the supervisor. He was in the canteen. He did not understand the urgency of the situation and said, "I will be there, will have a look". But by the time he actually showed up, it was too late."

Paralogical reasoning for Lyotard (1984) promotes dissensus. In the above paragraphs we find conflicting reasons for the shutdowns. While the telex message suggests that there were operational problems, hence the shutdowns, the employee perspective reveals a theatrical side to the shutdowns to control plant performance i.e. to keep costs of production low. It is not our purpose here to label a particular perspective as true/false. Instead, we want to showcase to the reader the heterogeneous nature of our petit récit.

Continuing with our examination of plant performance, a further telex, dated 06/05/1981, shows how R Oldford, President of Union Carbide Agricultural Products Company Inc., appointed a team in 1981 to develop a strategic plan for the facilities at Bhopal to assess among other things, the impact of the plant on UCIL financial performance, on UCC financial performance, new capital required, time to implement improved strategies, risks and compatibility with UCC product interests and technical capabilities. The task for the team was to consider "[a]11 reasonable options to improve the profitability of the Indian investment without penalising the overall profitability of UCC's Ag Chemicals business." New product options were also to be considered. However, any option that required a significant amount of new capital investment would be difficult to approve.

Examination of the 1981 Strategic Plan developed by the team confirms the problems facing the plant and also suggests that none of the predictions of the 1977 review discussed earlier, had come to fruition. According to the 1981 review, the I-Nol unit, which housed the alphanaphthol process that UCIL elected to develop in-house, as discussed earlier, was facing a number of engineering and process problems and was yet to be completed. All the other units of the plant were operating but capacity utilisation was only 50\%. Although a lot of work had already gone into reengineering the I-Nol unit and it had been significantly modified at a substantial cost, to achieve operational status a fresh $\$ 1.3$ million would be required, resulting in an unfavourable price variance of $\$ 1.8$ million and a time lag of 15-18 months. The review further states that the project had accumulated a loss of $\$ 5.1$ million in the last five years due to an oversized plant, low demand and spiralling project costs. Capacity utilisation posed the biggest problem. Although the Bhopal plant had a capacity of manufacturing 10,000 tonnes of pesticides, between 1977-81 consumption of pesticides fluctuated between 1500/2000 tonnes. Sales were affected by the availability of cheaper alternatives in the Indian market. Given that the main consumer of the pesticides manufactured in Bhopal was cotton, the review proposes 
long term diversification in new areas e.g. soya beans, corn, forest, horticulture, kitchen and home garden market. The report considers the overall financial impact of these new strategies as follows:

(\$ Million)

\section{$\begin{array}{lllll}1982 & 1983 & 1984 & 1985 & 1986\end{array}$}

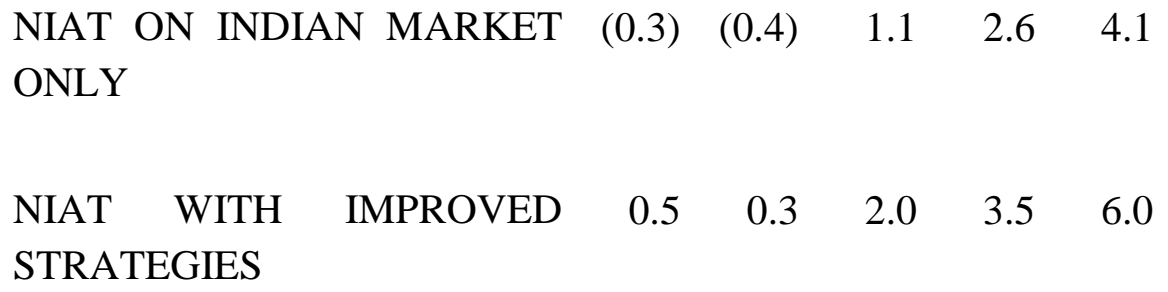

Relatedly, a telex from R Natarajan, the Director of the Agricultural Products Division of UCE to W Correa, Managing Director of UCIL, dated 11/06/1981 observes:

"The Bhopal problem is identical to Institute problem viz. an oversized plant with an undersized market. A major difference however is that whereas UCC has the financial strength to bet on the come, UCIL has to limit its additional investments at this stage to preferably what it can do with existing facility."

A telex from R J Hughes, Executive Vice President UCC, to J M Rehfield, Vice President UCC, dated 29/07/81, states that the sales estimates for the coming years for pesticides were overly optimistic in the 1981 Strategic Plan, given the entry of cheaper competitors in the market. Hughes observes that sales growth for UCIL pesticides had essentially been static for a number of years. Furthermore, the variable costs at the Indian plant were 3-4 times higher than that at the UCC Institute plant in West Virginia, while selling prices of the pesticides were more or less the same. His preliminary conclusions included indefinitely delaying the commissioning of the I-Nol unit supposed to produce alpha-naphthol, and instead import alphanaphthol from the UCC Institute plant at \$1 per pound free alongside ship. The telex finishes recommending the need for UCIL to develop long term plans with/without the I-Nol unit being operational and more conservative sales estimates to assess the possible extent of the "bleeding".

The discussion so far demonstrates how the metanarrative of performativity was governing the discourse around the Bhopal plant, through various accounting constructs. This focus on 
improving performativity continues in the year of the tragedy, when a long letter from $\mathrm{R}$ Natarajan to J B Law, the Chairman of UCE dated 24/02/1984 highlights the gravity of the situation. According to the letter, $\$ 30$ million was invested by UCIL in the Bhopal project. Net fixed investment, as of end 1983 was $\$ 18.1$ million and tax savings amounted to $\$ 9.8$ million. However, between 1978-83, the plant had a negative earnings performance of $\$ 7.5$ million. Expressing deep concern, Natarajan asks, "The UCIL Board is very keen to establish what UCC is going to do to resolve the problem." The letter argues that based on the financial results the future of the Bhopal project is very questionable. Competitors producing cheaper pesticides with lower fixed investments were dominating the market and market diversification efforts during 1981-83 (as discussed above) were not successful either. A major optimisation and improvement drive was carried out in 1983 which involved cutting 335 jobs and a saving of $\$ 1.25$ million but it would be difficult to repeat cost cuts of such a magnitude in the future.

The letter continues to discuss future business strategies and projections. Three scenarios are considered. First, UCIL would import alpha-naphthol from the UCC until 1985 and start manufacturing alpha-naphthol in Bhopal from 1986. We reproduce the financial projections detailed in the letter in such a scenario below:

(\$ Million)

$\begin{array}{llllll}1983 & 1984 & 1985 & 1986 & 1987 & 1988\end{array}$

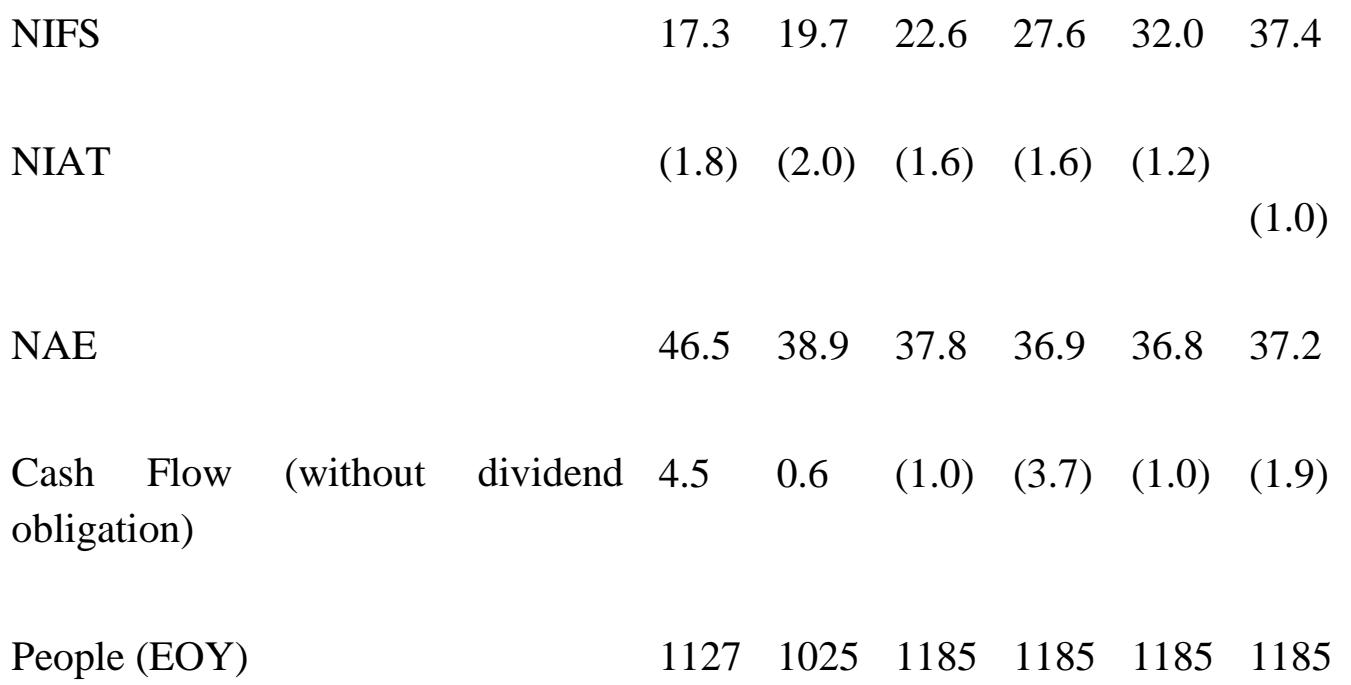

The second scenario involved UCIL writing off its problematic alpha-naphthol facility and buying alpha-naphthol from a local manufacturer from 1986. The financial projections were: 
(\$ Million)

$\begin{array}{llllll}1983 & 1984 & 1985 & 1986 & 1987 & 1988\end{array}$

\begin{tabular}{|c|c|c|c|c|c|c|}
\hline NIFS & 17.3 & 19.7 & 22.6 & 27.6 & 32.0 & 37.4 \\
\hline NIAT (Operation) & (1.8) & $(2.0)$ & (1.6) & (1.8) & (2.4) & $(2.3)$ \\
\hline $\begin{array}{l}\text { NIAT (caused by naphthol plant } \\
\text { write-off) }\end{array}$ & - & $(0.5)$ & $(0.4)$ & $(0.5)$ & 0.1 & 0.1 \\
\hline NIAT Total & (1.8) & $(2.5)$ & $(2.0)$ & (2.3) & (2.3) & $(2.2)$ \\
\hline NAE & 46.5 & 38.9 & 36.6 & 35.7 & 35.5 & 36.0 \\
\hline $\begin{array}{l}\text { Cash Flow (without dividend } \\
\text { obligation) }\end{array}$ & 4.5 & - & 0.2 & (3.8) & (2.3) & (3.3) \\
\hline People (EOY) & 1127 & 1025 & 1025 & 1025 & 1025 & 1025 \\
\hline
\end{tabular}

The negative cash flows in scenario 1 were mainly due to the uncertain costs associated with the recommissioning of the alpha-naphthol facility while those in scenario 2 were mainly due to the withdrawal of credit enjoyed on alpha-naphthol imported from the UCC Institute and higher price payable to local supplier for alpha-naphthol, when compared to production in the plant.

In light of the above figures and poor market conditions, according to the letter, UCIL and UCE suggested a strategic business change for the UCC to approve. Rather than manufacturing pesticides, the Bhopal plant would be used to manufacture and sell MIC alone. The logic being not only minimising NIAT and cash flow losses but also protecting the investment in MIC technology. The I-Nol unit would be written off for $\$ 3.5$ million and the other units, save the MIC unit, would be sold off. The financial projections were as follows:

(\$ Million) 
$\begin{array}{llllll}1983 & 1984 & 1985 & 1986 & 1987 & 1988\end{array}$

\begin{tabular}{|c|c|c|c|c|c|c|}
\hline NIFS & 17.3 & 19.7 & 3.7 & 4.6 & 5.1 & 6.1 \\
\hline NIAT (Operation) & $(1.8)$ & $(2.0)$ & $(0.8)$ & $(0.6)$ & $(0.4)$ & \\
\hline $\begin{array}{l}\text { NIAT from write-offs (whole I-Nol unit and } \\
\text { parts of other units) }\end{array}$ & - & $(0.6)$ & $(1.4)$ & $(0.8)$ & - & - \\
\hline NIAT from separation costs (approx. 700 men) & - & - & $(0.9)$ & - & - & - \\
\hline NIAT from inventory write-off and bad debts & - & - & $(1.0)$ & - & - & - \\
\hline NIAT Total & $(1.8)$ & $(2.6)$ & $(4.1)$ & $(1.4)$ & $(0.4)$ & $(0.3)$ \\
\hline NAE & 46.5 & 38.9 & 9.6 & 9.8 & 9.8 & 10.0 \\
\hline Cash Flow (without dividend obligation) & 4.5 & 0.6 & 11.0 & $(0.3)$ & $(0.5)$ & $(0.5)$ \\
\hline People (EOY) & 1127 & 1025 & 337 & 337 & 337 & 337 \\
\hline
\end{tabular}

According to the aforementioned letter, UCIL would try to achieve at least breakeven NIAT and Cash Flow. However, if the MIC business did not meet the predictions, UCIL would maintain estimated losses by writing off the MIC unit for an additional $\$ 10.5$ million. The letter ends with Natarajan seeking endorsement of the UCC for scenario 3 with the caveat that it would be difficult to find a buyer for the non MIC facilities since "no one in Pesticide Industry in India (or in fact in any other part of South East Asia) has put in such a massive investment except the UCIL" (Natarajan, 1984).

The above section demonstrates the extent to which the metanarrative of performativity, through various accounting measures, was defining plant operations. It also shows the power of performativity in legitimising itself and legitimising the notion of a stable system which can be controlled perfectly via the perfect input/output ratio. As Spicer, Alvesson \& Kärreman (2009, p. 541) observe, "Performative knowledge is legitimate not because it is true, but because it has a technical value associated with producing results." The various financial projections examined above reduce the Bhopal plant to accounting numbers that help sustain the illusion that all is in control (Hines, 1988), and that if a particular scenario is endorsed, the 
plant will follow the trajectory charted by the accounting numbers from $1983-88$ and the maximisation of efficiency (i.e. NIAT) will/will not, be possible, removing any equivocality by providing predictive reliability (Paparone, 2017). The next section of our discussion evaluates the impact of such accounting considerations on the safety of the Bhopal plant and in the process call into question the lofty claims of safety professed by the annual reports.

\section{Plant safety}

Given the nature of the disaster, a lot has been written about the compromises in safety made in the Bhopal plant. Prior work (e.g., Everest, 1986, pp. 46 - 47; Lapierre \& Moro, 2003, pp. 205 - 206; Hazarika, 1987, p. 63) suggests that during 1982-1984, permanent employment at the Bhopal plant was reduced from 850 to 642 and 300 temporary workers were made redundant. The number of operators in charge of the MIC unit was cut from twelve to six and in the crucially important control room of the MIC unit, "...only one man was left in charge of some seventy dials, counters and gauges, which relayed, among other things, the temperature and the pressure of the tanks containing the MIC" (Lapierre \& Moro, 2003, p. 205). Badhwar \& Trewan (1984, p. 10) state that in contrast to $1977-78$ when only first-class BSc graduates were appointed as plant operators after six months theoretical and practical training, in the 80s, even those without an academic science background were being appointed as operators, with very little training. Hazarika (1987, p. 63) observes that the majority of the plant operators were high school graduates without degrees in chemical engineering and could hardly read or write in English, although, the operating manuals of the Bhopal plant were only in English. Diamond (1985) states that plant workers had virtually no knowledge of handling non-routine events. Everest (1986, p. 47) points out that often people from other units were transferred to Bhopal. For instance, at the time of the disaster, the head of the agricultural products division, who was responsible for overseeing operations in Bhopal, was someone who had just been transferred from UCIL's battery division.

Relatedly, the report of a Safety Audit carried out by the three UCC engineers in May 1982 observes that a number of possibilities existed for serious personnel exposure to toxic materials during routine maintenance or operations, mainly due to leaking valves which were found to be fairly common. In relation to high labour turnover, the safety audit describes it as a "serious problem" because this made training and understanding of the various processes paramount. However, people were allowed to work independently without adequate training which was very alarming to the team. They cite an example of an operator who was allowed to work in the storage/unloading area after only 2 months basic training. The nature of training was also called into question. Rather than train workers for 'what if' scenarios' and encourage them to develop an understanding of the logic behind the various processes, workers were required to blindly memorise the steps. 
These compromises in safety were the manifestations of the major optimisation and improvement drive alluded to by R Natarajan in his letter to J B Law, as discussed in the preceding section. The drive was carried out in 1983 with the objective to save \$1.23 million, resulting in the loss of 335 jobs and dramatic cost cuts. In his sworn testimony, in a case filed against the UCC in the United States District Court, Southern District of New York in April 2000, Kamal Pareek who was the Safety Superintendent at the pesticide factory in Bhopal from 1981 - 1983 observed:

\begin{abstract}
"By 1983, Union Carbide in America had become concerned about the financial losses at UCIL in Bhopal. UCIL was losing a considerable amount of money at that time. So, in order to save profits, Union Carbide's management in America launched an economy and cost-cutting drive that essentially reduced the UCIL facility to operating on the barest minimum requirements. This drive meant we started using bits and pieces of equipment which were better thrown away: for instance, gaskets and pieces of pipelines. We welded them together and used them. So, when something cost may be Rs. 10,000 for a piece of pipe which has a hole in it, instead of throwing away the pipe and replacing it, we would simply patch up the hole and use it again. Over time, Union Carbide's policy meant that the UCIL plant lost qualified people. The plant was forced to operate with short crew, short manning. Some people operating the MIC plant were not, in my opinion, properly trained or qualified to do so" (Court document 99 Civ, 11329 (JFK).
\end{abstract}

However, the schedules to accounts in the UCIL 1984 Annual Report show an increase in 'Salaries, Wages and Bonus' from Rupees 2107 lakhs in 1983 to Rupees 2184 lakhs in 1984 for the company as a whole. The Schedules distinguish between permanent and temporary employees, earning more than Rupees 3000 per month. In both categories there is an increase in the number of employees between 1983 and 1984. While the number of permanent employees went up from 995 to 1152, the number of temporary employees increased from 66 to 107. It is true that the figures do not relate to the Bhopal plant specifically, but it can be argued that they give the impression that the company (including the Bhopal plant) was expanding and consequently appointing new employees, both on a permanent and on a temporary basis. The numbers, a part of the dominant organizational narrative, suggest progress and growth. The fact that employees were being made redundant at the Bhopal plant would never occur to the reader.

Contrary to the claims of safety in the UCC and UCIL Annual Reports, three accidents took place in the Bhopal plant before the tragedy. In December 1981, a plant operator inhaled gas while repairing a faulty valve and died shortly afterwards. Six weeks later, 16 workers were seriously injured when a pump failed prompting a gas leak. In his testimony, Kamal Pareek further observed that UCC officials were visiting the Bhopal plant on that day and were well aware of the accident. However, all that happened in response to the accident was the 
organisation of a safety week. In October 1982 another gas leak occurred affecting the people living in the slums around the plant. Several workers were injured, a lot of chaos ensued in the neighbouring communities with people running away to save their families. In spite of all these accidents, as Pareek observes:

"During my entire tenure at UCIL, no evacuation plan of any kind was ever put in place to help the people of these surrounding colonies escape in the event of an emergency" (Court document 99 Civ, 11329 (JFK).

T R Chouhan a former employee at the Bhopal plant, when interviewed by the Bhopal Group for Information and Action (BGIA) in 1984 about cost cutting at the plant stated:

"Naphthol drums were broken open manually by casual workers. For each drum they got Rs 5. To make more money they would open 20-25 drums a day but would fall sick the next day and make no money. Permanent workers would have done this work only by proper procedure and after insisting on using safety equipment, which is why it was never given to them." (BGIA, 1984)

The above discussion on safety calls for a reflection on the essay, 'After Bhopal' in the 1984 UCC Annual Report. The claims of discussing early warning and preparedness programmes, sharing the knowledge of chemicals being manufactured and their associated risks with local communities and the call for a nationwide hazard system, all, come across as gimmicks, designed strategically to play to the target audience i.e. the shareholders to showcase the commitment to safety and allay any fears of a similar tragedy occurring in the US. This is further illustrated by the corporation's claim that it had invested millions of dollars in the US in particular, in safety and that Bhopal might be the result of a developing economy not being able to handle sophisticated Western technology. We wish to argue that the claims made in the essay are all underpinned by the metanarrative of performativity. The essay reports that two countries had refused to accept shipments of methyl isocyanate after Bhopal. The company's safety credentials were being questioned not only in the US but across the world. This must have been unsettling for the shareholders of the UCC which explains the reason for UCC stock plummeting from $\$ 50$ - \$58 before Bhopal to $\$ 32$ - $\$ 40$, prompting speculative activity. Lyotard (1984, p. 45) suggests that performativity entails an equation between wealth, efficiency and truth. The truth about Bhopal i.e. the horrific effects of chemicals used in the manufacture of pesticides and the unfolding economic consequences as discussed above, made the company come across as an inefficient proposition for investment with the potential for driving away current and future investment in the company. So, the essay, may be seen as "...a carefully manipulated sales pitch" (Bonnell II 1982, p.35), typical of annual reports, to reassure 
the providers of capital that lessons had been learned from Bhopal and that the company had a future.

However, when we raised the issues of safety and training with the former employees of the Bhopal plant, one refused to comment while the other responses were contradictory. We reproduce excerpts from our interviews below:

[1] Nothing was wrong with my plant. Absolutely nothing. Do not believe what you read in the books. You are now hearing it straight from the horse's mouth. It was an unfortunate accident. There were never any cuts to safety or to training. Do not believe what others tell you.

[2] Training? A lot of training was provided. Mock drills were carried out in the plant. Every single employee in the factory, in every department, even those in Stores, would be trained in what to do if there was a fire, gas leak etc. So much training in safety was provided that us employees would say to each other that they are making fools out of us. What is the point of so much training? Yes, we were told about managing costs almost every day but that did not mean defective pipes would be used. Any item with the slightest bit of defect would be replaced immediately. We were told to make reasonable adjustments. For example, workers would sometimes throw away perfectly functional bits and pieces. They had arrangements with the scrap buyers, who would tell them what to include so that the scrap would fetch a high value. Kind of corruption. If we found something lying unused on the factory floor, we would take it to Stores, wink at the Stores Manager to say that I am taking this home and then buy something almost completely new at a nominal price. If something cost Rupees 1000, we would get it for Rupees 100. For example, I used to get brand new steel oil drums at a nominal price to store water at home. Management would try to control these things.

Others however, endorsed the compromises to training and safety. We were told that leaks were routine at the plant and that safety had taken a back seat right from the very beginning to economise on costs. For example, pits would be dug across 21 locations on the factory premises and toxic waste would be dumped into them. No proper waste removal procedures were followed, to keep operational costs under control. According to the former employees, even if the MIC tank had not exploded on Dec 3, 1984, contamination from toxic waste would eventually lead to tragic consequences in Bhopal (as manifested by the contamination of the groundwater reserves of the city, discussed earlier). We also learned that modifications were made in the design of the safety mechanisms of the Bhopal plant to keep costs low. In particular, a 'knock down tank', an integral part of the UCC MIC plant in West Virginia, used 
to slow down the velocity of the escaping MIC gas in case of a leak so that the gas could be burned off in its entirety, was missing from the design of the Bhopal MIC unit.

\section{The terror of performativity - the final hours}

Lyotard (1984) equates the stifling of the heterogeneous nature of discourse by the power of the performativity criterion with terror. Anything that does not maximise efficiency is marginalised and made to disappear. We assert that the terror of performativity manifested itself in the failure of the safety systems on the night of the tragedy.

MIC was stored in steel tanks and cooled by a refrigeration unit that would maintain temperatures below $5^{\circ} \mathrm{C}$. Low temperatures would make the MIC a lot less reactive. However, the refrigeration unit had been shut down for over five months prior to the accident. Scholars such as Everest (1986), Shrivastava (1987) and Eckerman (2005) observe that the freon refrigerant had been drained out for use elsewhere in the plant. As a consequence, on the day of the tragedy, tank temperatures ranged between $15-20^{\circ} \mathrm{C}$ instead of the preferred $0-5^{\circ} \mathrm{C}$. According to the testimony of Kamal Pareek, a former safety officer at the Bhopal plant, it cost UCIL Rs500 - Rs700 daily to run the refrigeration unit. Given the insignificance of the daily cost in terms of dollars, the decision to drain the freon refrigerant could only have been made to save the cost of electricity or freon gas (Court document 99 Civ, 11329 (JFK)). During our interviews with the former employees of the plant we learnt that the decision to shut down the refrigeration unit was based on a simple accounting logic - the loss from evaporation of MIC by storing it at an ambient temperature was lower than the cost of running the refrigeration unit.

Other than the refrigeration unit, a vent gas scrubber (VGS) installed to neutralise toxic gases with caustic soda in the event of a release, was also out of order. The VGS was non-operational since October 1984 because supervisors thought that it was not necessary. According to a former employee:

When we put forward the caustic soda requirements [for the VGS], we were told by senior management, 'What is the point? There is no need." In my opinion, if these people had been honest, if they had maintained the scrubber even when the factory was incurring losses, for the purposes of safety, the tragedy would not have happened.

The fact that maintaining the above vital safety systems was no longer a part of the discourse on the Bhopal plant, is for us symptomatic of the terroristic consequences of performativity. 
As Guérard et al. (2013, p. 570) observe, the preoccupation with performance drives other issues out of consideration, the focus narrows down to "...what can be measured rather than to the raison-d'être of the enterprise." Both the UCC and UCIL management were exercising no reflexivity regarding the morality of their decisions of not maintaining the safety systems (see Paparone, 2017). They were simply viewing the Bhopal plant as an inefficient, loss making oversized plant in an undersized market. The best input/output ratio in such a scenario entailed spending the bare minimum to keep the plant going. A letter dated 26/10/1984 from R Natarajan, the Director of the Agricultural Products Division of UCE to UCIL Vice President K S Kamdar, considering the probability of dismantling the Bhopal plant, suggests that both the UCC and UCIL had completely given up on the operations in Bhopal. According to the letter, the MIC unit would be installed in Brazil and the other units in Indonesia. Natarajan asked Kamdar to prepare a feasibility report with an estimate of the costs. Kamdar sent a telex response dated 13/11/1984 where he states that the shipment of the MIC unit might be problematic because of high corrosion in the pipework but the shipment of the other units is possible. A draft of a telex message which was supposed to be sent to Natarajan regarding the dismantling suggests that it would cost $\$ 1.3$ million plus/minus $25 \%$ to decontaminate, dismantle and transport the various units of the Bhopal plant to Bombay. Freight charges from Bombay to Surabhaya (Indonesia) would be $\$ 249$ million and that from Bombay to Mexico Port would be $\$ 1400$ million.

The consequences of the failure of the safety systems were catastrophic and led to what is often described as the worst industrial disaster of the world. During our interviews, we invited our participants to reflect on the nature of events that night. Almost all the interviewees were in bed when the explosion occurred. They described the smell of MIC as that akin to chillies being cooked on an open fire. As soon as they inhaled the gas, their throats and eyes started to burn, and they suffered from uncontrollable coughing fits. Very few people knew what the gas was and that it was escaping from the factory. Most decided to run thinking either riots had started, and bombs were exploding or that the end of the world had come, and it was Judgement Day. Others decided to stay indoors to face any eventuality together, as a family. Our interviewees described the scene on the streets of Bhopal that night as 'hellish'. We reproduce short excerpts from our interviews in an attempt to impart a sense of the unpresentable to the reader, which for Lyotard (1984, p. 81) is the task for the postmodern writer.

"On the streets, it seemed the end of the world had come. People were running like mad. Some were even in their underwear. It was winter but they did not wait to put on clothes. Life is precious you know. They were trampling over one another, driving over one another, no one stopped for anyone. Entire families, like those who chose not to run and locked themselves in their homes, died that night. We lost all our livestock. Everything was destroyed that night." 
"There was a lot of commotion outside. We were in bed. My father opened the door when he heard the screams outside. You see the gas was flowing a bit higher than ground level so as soon as he opened the door, more gas entered the house. We all started coughing very badly. There was so much gas that the electric bulb seemed like a distant candle. We started running, barefoot. My eyes were so swollen that I had to force them open with my fingers. I would walk a little, try to open my eyes and see and walk again."

"When we returned home in the morning, people were still running away from Bhopal. There were many bodies on the deserted roads. People were foaming at the mouth. Some were defecating, some urinating, some lying unconscious. At the local Hamidia Hospital there were piles of bodies, thousands of them, some unconscious, some dead. Some were cremated, others taken by trucks and dumped in the lake."

Though beyond the remit of presentation, we try to allude to the horrific nature of events as they unfolded on December 3, 1984, through the above excerpts. For us, they showcase the consequences of the terror of performativity. We see how an obsession with the maximisation of efficiency, predicated on an illusion of total control over a system, all actualised via the language of accounting, claimed thousands of innocent lives and incapacitated many more.

The discussion so far demonstrates how our locally rooted petit récit on the Bhopal Gas Tragedy offers a different perspective on the crisis, calling into question the claims of safety and responsibility, advocated by the UCC and UCIL annual reports. As noted by Hassard \& Kelemen (2002, p.339), a postmodern approach entails an alternative explanation for the state of affairs, one that is rooted in the 'local' rather than the 'grand' genres of intellectual discourse. Thus, while the annual reports proclaim the successful performance of the companies in 1984, despite the setback of Bhopal, our paralogical evaluation and the resultant little narrative exposes, from multiple perspectives, how right from the very beginning, the Bhopal plant was plagued by the metanarrative of performativity. We can see how an oversize plant was constructed in an undersized market using untested technology, inferior quality materials and faulty design to economise on costs in the quest for the best input/output ratio. Strategic reviews suggest that the forecasts regarding the Indian pesticides market turned out to be grossly incorrect and attempts to diversify also failed miserably. Saddled with a loss-making plant, telex messages exchanged between the UCC and UCIL indicate pressures to stop this "bleeding" (Hughes, 1981). Maximising performativity through accounting considerations, such as minimising negative cash flows and net income after tax reigned supreme leading to staged shutdowns and dramatic cuts to safety and training. Internal telex messages also suggest that even the dismantling and shipment of the plant to Brazil/Indonesia were being considered. However, the UCC and UCIL annual reports are completely silent about the proposed uninstallation of the Bhopal plant i.e. the organizational narratives do not let the reader sense any discontinuity in relation to Bhopal. In fact, when questioned by a reporter at a press 
conference on 20/03/1985 in Danbury, Connecticut, on the reason for the presentation of the UCC investigation report not containing any references to “...underdesign, cost cutting, sloppy maintenance, because many of the people thought the factory was going to be sold?", Warren Andersen, the Chairman of the UCC responded that the report was about what happened in the tank and evaded talking about these issues completely. Instead he started talking about the difficulty of gaining access to the tank since the Government of India had sealed the premises.

We also wish to remind the reader about the heterogeneous nature of our petit récit that seeks to promote dissensus in the spirit of Lyotard's (1984) call for legitimation by paralogy. Jones (2003, p. 520) observes that paralogy makes us confront the complex nature of our arguments and stresses the constant need for revision to bring to light that which has been marginalised. In relation to training and safety, our research shows mixed results with some former employees suggesting that a lot of training was provided, very high standards of safety were maintained and asserting that Bhopal was indeed an accident, while others arguing otherwise, echoing existing scholarship on the issue. It is not our intention to engage in a debate as to which of these perspectives is true. Rather, as is the case with Maori tribal histories (Hokowhitu, 2009; Hokowhitu \& Page, 2011), we want to showcase the competing perspectives and the disagreements within our locally determined little narrative to illustrate that our petit récit is incomplete and that the search for alternative perspectives on Bhopal must continue.

\section{Concluding remarks}

Drawing on the seminal work of Lyotard (1984), this paper examines the role of accounting in the machinations of an industrial disaster. We show how a preoccupation with maximisation of efficiency actuated through accounting constructs led to the construction of a plant with untested technology and inferior quality materials in Bhopal and was instrumental in marginalising issues related to training, maintenance and safety. Our findings suggest that dramatic cuts were made to the number of trained personnel, the standards of training and the expenditure on safety to economise on costs. Such was the power of the performativity criterion that on the night of the tragedy, none of the safety systems in the plant were functional. Indeed, safety had ceased to be a part of the discourse around the plant since it did not promote economic efficiency. A paralogical evaluation, however, avoids the creation of a consensus so that there is no one dominant standpoint and the quest for alternative interpretations can continue (Lyotard, 1984). Accordingly, our little narrative also presents dissenting views regarding falling standards of training and safety which suggest that a lot of training was provided, and that safety was always the number one priority. The focus of cost minimisation was on cutting down corruption in the form of unnecessary repairs and maintenance. 
As discussed, performativity is predicated on an illusion of perfect control over a system, where all the variables are assumed to be known in advance (Lyotard, 1984). Our paper shows how such an illusion led to the design of an oversized plant in Bhopal, as a consequence of which production always exceeded demand. We further argue that the calculative technologies of accounting is deeply embedded in the choice of variables that constitute a system (Hines 1988) and play a critical role in sustaining the fiction that all is under control. Various financial projections such as cash flows, gross margins, overheads, ratios such as NIFS, NIAT and ROA reduced the Bhopal plant to accounting constructs and helped sustain the utopia that if a particular scenario was endorsed, the plant would follow the trajectory charted by the accounting numbers and the maximisation of efficiency (i.e. NIAT) would be achievable.

In line with scholars in a range of other disciplines who have drawn on Lyotard (1984), we have demonstrated how the preoccupation with performativity results in a loss of focus (Rowlands, 2012; Kalfa \& Taska, 2017) and reflexivity (Paparone, 2017). The maximisation of efficiency becomes so important that attention is no longer paid to the morality of action. Building on existing research that examines the role of accounting in disasters (e.g., Matilal \& Hopfl, 2009; Baker, 2014; \& Perkiss \& Moerman, 2017, 2018) our study has granted visibility to multiple, conflicting perspectives in the form of internal documents and observations of former employees which would have otherwise remained in the margins. Our arguments in the paper are also in line with those of Baker (2014), Taylor et al. (2014), Sargiacomo et al. (2014) and Sargiacomo (2015) about the preoccupation of accounting with that which can only be measured and rationalised in numerical terms. In doing so, we agree with Taylor et al. (2014) and Sargiacomo et al. (2014) that accounting has a responsibility that extends beyond the providers of capital.

Having said that we have contributed to the critical accounting literature in two ways. Empirically, in contrast to the aforementioned accounting and disaster scholarship that has mostly focused on the role of accounting in the aftermath of tragedy or on governmental negligence leading to tragedy (Cooper et al., 2011; Siddiqui \& Uddin, 2016), our paper looks at the deep-seated nature of accounting measures in the makings of a catastrophe. Theoretically, by drawing on the work of Jean-Francois Lyotard (1984), in particular his notions of performativity and legitimation by paralogy, we have developed a heterogenous locally rooted petit récit or little narrative that questions the facade of safety and responsibility advocated by annual reports in the aftermath of an industrial disaster. Our incomplete little narrative developed from multiple sources delineates how the quest for the perfect input/output ratio and the illusion of perfect control over the system, actualised by accounting constructs, were instrumental in the construction of a plant characterised by faulty design, poor maintenance and possible compromises to training and safety, leading to disastrous consequences. 
Finally, we call for further research on the relationship between accounting and the formulation of catastrophe. Such research may help us further theorise the role of accounting in the design of industrial disasters, an issue which has received relatively limited attention from critical accounting researchers. The ethical dimension of decision making on the basis of accounting constructs, particularly in hazardous industries, also warrants attention. Relatedly, the use of the calculative technologies of accounting by the State in the prevention of natural and humanitarian disasters may also provide an avenue for further research.

\section{References}

Abraham, C.M., \& Abraham, S. (1991). The Bhopal case and the development of environmental law in India. The International and comparative law quarterly, 40(2), 334-365.

Agyenim-Boateng, C. and Oduro-Boateng, K. (2019) Accounting for disasters. Journal of Accounting in Emerging Economies, 9(3), 422-448.

Alavi, S. (2017). 'Nobody bothers about us': survivors of Bhopal gas leak speak of extreme apathy 33 years after the catastrophe. Huffington Post India. Retrieved 7 March 2018, from https://www.huffingtonpost.in/2017/12/04/nobody-bothers-about-us-survivors-of-bhopal-gasleak-speak-of-extreme-apathy-33-years-after-the-catastrophe_a_23296037/

Amernic, J., \& Craig, R. (2017). CEO speeches and safety culture: British Petroleum before the Deepwater Horizon disaster. Critical Perspectives on Accounting, 47, September, 61-80.

ANI. (2017). 33rd year of Bhopal gas tragedy; city still cries foul. Business Standard. Retrieved 15 January 2018, from https://www.business-standard.com/article/news-ani/33rd-year-ofbhopal-gas-tragedy-city-still-cries-foul-117120300068_1.html

Arrington, C. E., \& Francis, J. R. (1989). Letting the chat out of the bag: Deconstruction, privilege and accounting research. Accounting, Organizations and Society, 14(1-2), 1-28.

Austin J. L. (1962). How to Do Things with Words. Oxford: Oxford University Press. 
Ayub, J. (2013). Gas activists livid as doctors go high on spirit. The Times of India. Retrieved 15 January 2018, from https://timesofindia.indiatimes.com/city/bhopal/Gas-activists-livid-asdoctors-go-high-on-spirit/articleshow/26280739.cms

Badhwar, I., \& Trewan, M. (1984, December 31). Bhopal: City of death. India Today, 4-10.

Baker, C.R. (2014). Breakdowns of accountability in the face of natural disasters: the case of Hurricane Katrina. Critical Perspectives on Accounting, 25(7): 620-632.

Ball, S. J. (1998) Performativity and fragmentation in 'postmodern schooling.' Postmodernity and the Fragmentation of Welfare, 187-203.

Bang, R. (1985). Effects of the Bhopal disaster on the women's health - An epidemic of gynaecological disorders. In V. Pinto \& S. D. O'Leary (Eds.), Selected documents on the December 1984 Union Carbide chemical incident (pp. 35-37). San Francisco, C.A.: Washington Research Institute.

Belkaoui, A. (1978). Linguistic relativity in accounting. Accounting, Organizations and Society, 3(2), 97-104.

Belke, J.C., \& Dietrich, D.Y. (2005). The post-Bhopal and post-9/11 transformations in chemical emergency prevention and response policy in the United States. Journal of Loss Prevention in the Process Industries, 18(4), 375-379.

Bhopal disaster 35 years on: what happened? (2019, February 15) Retrieved 15 May 2019, from https://www.theweek.co.uk/99635/bhopal-disaster-35-years-on-what-happened

Bhopal Gas Peedit Mahila Udyog Sangathan v UCC \& Warren Andersen, US District Court of Southern District of New York, 27 April 2000, 99 Civ, 11329 (Affidavit of Kamal Pareek) 
Bhopal Group for Information \& Action (BGIA). (1984). Interview with T R Chouhan, Sambhavna Trust Library, Bhopal.

Bonnell II, W. (1982). Designers tread line between annual report and 'sales pitch. Industrial Design, November/December: 41.

Bowman, E., \& Kunreuther, H. (1988). Post-Bhopal behaviour at a chemical company. Journal of Management Studies, 25(4), 387-400.

Cabantous, L., Gond, J.P., Harding, N., \& Learmonth, M. (2016). Critical Essay: Reconsidering critical performativity. Human Relations; Studies towards the Integration of the Social Sciences, 69(2), 197-213.

Callon M (ed.). (1998). The Laws of the Markets. Oxford: Blackwell.

Callon, M. (2007). What does it mean to say that economics is performative? In D. MacKenzie, F. Muniesa, \& L. Siu (Eds.) Do Economists Make Markets? On the Performativity of Economics (pp. 310-357). Princeton University Press.

Case, P. and Piñeiro, E. (2006). Aesthetics, performativity and resistance in the narratives of a computer programming community." Human Relations; Studies towards the Integration of the Social Sciences, 59 (6), 753-82.

Cassels, J. (1993). The Uncertain Promise of Law: Lessons from Bhopal. Toronto: University of Toronto Press.

Chiapello, E. (2007). Accounting and the birth of the notion of capitalism. Critical Perspectives on Accounting, 18(3), 263-296.

Cooper, R. \& Burrell, G. (1988). Modernism, postmodernism and organizational analysis: An Introduction. Organization Studies, 9(1), 91-112. 
Cooper, C. (1997). Against postmodernism: Class oriented questions for critical accounting. Critical Perspectives on Accounting, 8(1-2), 15-41.

Cooper, C., Coulson, A., \& Taylor, P. (2011). Accounting for human rights: Doxic health and safety practices - The accounting lesson from ICL. Critical Perspectives on Accounting, 22 (8), $738-758$

Cooper, C. \& Lapsley, I. (2019). Hillsborough: The fight for accountability. Critical Perspectives on Accounting (in press)

Cowen, R. (1996). Performativity, post-modernity and the university. Comparative Education, $32(2), 245-258$.

Craig, R., \& Amernic, J. (2008). A privatization success story: accounting and narrative expression over time. Accounting, Auditing \& Accountability Journal, 21(8), 1085 - 1115.

Czarniawska, B. (2001) Having hope in paralogy. Human Relations, 54(1), 13-21.

D'Silva, T. (2006). The Black Box of Bhopal: A Closer Look at the World's Deadliest Industrial Disaster. Victoria, BC: Trafford Publishing.

De, S. (2012). Retrospective analysis of lung function abnormalities of Bhopal gas tragedy affected population. The Indian Journal of Medical Research, 135(2), 193-200.

Dhara, R. (1992). Health effects of the Bhopal gas leak: A review. Epidemiologia E Prevenzione, 14(52), 22-31.

Dhara, V.R. \& Dhara, R. (2001). The Union Carbide disaster in Bhopal: a review of health effects. Archives of environmental health, 57(5), 391-404. 
Dhara, V.R., \& Kriebel, D. (1993). The Bhopal gas disaster: it's not too late for sound epidemiology. Archives of environmental health, 48(6), 436-437.

Diamond, S. (1985, March 21). Union Carbide's inquiry indicates errors led to India plant disaster. New York Times, A1, D23.

Dutta, S. (2017). Bhopal Gas Leak: 33 Years On, No Solution for Idle Toxic Waste At The Site That Continues To Pollute The Environment. NDTV.com.

Retrieved 7 March 2018, from

https://swachhindia.ndtv.com/bhopal-gas-leak-33-years-on-no-solution-for-idle-toxic-wasteat-the-site-that-continues-to-pollute-the-environment-15490/

Eagar, T., \& Dann, S. (2016). Classifying the narrated \#selfie: Genre typing human-branding activity. European Journal of Marketing, 50 (9/10), 1835-57.

Eckerman, I. (2005). The Bhopal saga: Causes and consequences of the world's largest industrial disaster. Hyderabad: Universities Press.

Everest, L. (1986). Behind the Poison Cloud: Union Carbide's Bhopal Massacre. Chicago: Banner Press.

Ezzamel M., \& Hoskin K. (2002). Retheorizing accounting, writing and money with evidence from Mesopotamia and ancient Egypt, Critical Perspectives on Accounting, 13(3), 333-367.

Fletcher, I.C., Ono, T. \& Roy, A. (2005). Justice for Bhopal. Radical history review, 2005(91), 7-12.

Fortun, K. (2009). Advocacy after Bhopal: Environmentalism, Disaster, New Global Orders. Chicago: University of Chicago Press. 
Fournier, V., \& Grey, C. (2000). At the critical moment': conditions and prospects for critical management studies. Human Relations 53(1), 7-32.

Francis, A. (2014). Why are Bhopal survivors still fighting for compensation? BBC News. Retrieved 7 March 2018, from http://www.bbc.co.uk/news/world-asia-india-30205140.

Funnell, W. (1998). Accounting in the service of the holocaust. Critical Perspectives on Accounting, 9(4), 435-464.

Galanter, M. (1986). When legal worlds collide: Reflections on Bhopal, the good lawyer, and the American law school. Journal of legal education, 36(3), 292-310.

Gallhofer, S., \& Haslam, J. (1991). The aura of accounting in the context of a crisis: Germany and the First World War. Accounting, Organizations and Society, 16(5/6), 487-520.

Gas victims demand CBI probe into alleged rehabilitation fraud. (2014). The Hindu. Retrieved 15 January 2018, from_http://www.thehindu.com/news/national/other-states/Gas-victimsdemand-CBI-probe-into-alleged-rehabilitation-fraud/article11485173.ece

Garrick, J. \& Chan, A. (2017). Knowledge management and professional experience: The uneasy dynamics between tacit Knowledge and performativity in organizations. Journal of Knowledge Management 21 (4): 872-84.

Giroux, H. (1992). Border Crossings. Cultural Workers and the Politics of Education. New York: Routledge.

Goddard, E. (2017). Bhopal disaster victims may never get compensation following DowDuPont merger, fears UN official. The Independent. Retrieved 15 January 2018, from http://www.independent.co.uk/news/business/news/bhopal-disaster-victims-dow-dupontmerger-un-india-official-gas-leak-chemical-industrial-a7946346.html 
Gond, J., Cabantous, L., Harding, N., \& Learmonth, M. (2016) What do we mean by performativity in organizational and management theory? The uses and abuses of performativity. International Journal of Management Reviews, 18(4), 440-63.

Guérard, S., Langley, A., \& Seidl, D. (2013). Rethinking the concept of performance in strategy research: Towards a performativity perspective. Management 16(5), 566-78.

Gumb, B., Dupuy, P., Baker, C. R., \& Blum, V.(2018). The impact of accounting standards on hedging decisions. Accounting, Auditing \& Accountability Journal, 31(1),193-213.

Gupta, S. (2013). No grooms for Bhopal gas victim girls. The Times of India. Retrieved 15 January 2018, from https://timesofindia.indiatimes.com/city/bhopal/No-grooms-for-Bhopalgas-victim-girls/articleshow/26702667.cms

Harvey, D. (1989). The Condition of Postmodernity. Cambridge: Wiley-Blackwell.

Hassard, J. \& Kelemen, M. (2002). Production and consumption in organizational knowledge: The case of the 'paradigms debate'." Organization 9 (2): 331-55.

Hazarika, S. (1987). Bhopal: The Lessons of a Tragedy. New Delhi: Penguin Books.

Hines, R. (1988). Financial accounting: in communicating reality, we construct reality. Accounting, Organizations and Society, 13(3), 251-261.

Hines, R. D. (1992). Accounting: filling the negative space. Accounting, Organizations and Society, 17(3-4), 313-341.

Hokowhitu, B. (2009). Māori culture: Contemporary or not? MAI Review 3(3): 3.

Hokowhitu, B. \& Page, T. (2011). Postcolonial peace. Junctures: The Journal for Thematic Dialogue, no. 14. 
Hopwood A. (1996). Making visible and the construction of visibilities: Shifting agendas in the design of the corporate report Introduction. Accounting, Organizations and Society, 21, 55 $-56$.

Hoskin, K.W., \& Macve, R.H. (1988). The genesis of accountability: The west point connections. Accounting, Organizations and Society, 13(1), 37- 73.

Hoskin, K., \& Macve, R. (1994). Reappraising the genesis of managerialism: a re-examination of the role of accounting at the Springfield Armory, 1815-1845. Accounting, Auditing and Accountability Journal, 7(2), 4-29.

Hughes, R J. (1981). Telex to J N Rehfield, Sambhavna Documentation Centre.

Ice, R. (1991). Corporate publics and rhetorical strategies: the case of Union Carbide's Bhopal Crisis. Management Communication Quarterly, 4(3), 341-362.

ICMR. (2004). Health Effects of the Toxic Gas Leak from the Union Carbide Methyl Isocyanate Plant in Bhopal, Technical report based on population based long term epidemiological studies (1985 - 1994). Indian Council of Medical Research, New Delhi.

Iyengar, R. \& Bajaj, M. (2011). After the smoke clears: toward education for sustainable development in Bhopal, India. Comparative education review, 55(3),424-456.

Irving, R. (2015). Multiple narratives in a performative further education context, with reference to Lyotard's 'The Postmodern Condition', University of Bath Working Papers Series No. 2015/13. Retrieved 16 August 2019, from

http://www.bath.ac.uk/education/documents/working-papers/multiple-narrativesperformative-further-education-lyotards-postmodern-condition.pd

Jain, R. (2019, January 26) Bhopal gas tragedy: Eyes wide shut. The Hindu 
Jasanoff, S. (1994). Learning from Disaster: Risk Management After Bhopal. Pennsylvania: University of Pennsylvania Press.

Jameson, F. (1984). Foreword. In Lyotard J. F. The Postmodern Condition: A Report on Knowledge (G. Bennington and B. Massumi trans.) Manchester: Manchester University Press.

Jones, C (2003) “Theory after the Postmodern Condition.” Organization 10 (3): 503-25.

Kalfa, S. \& Taska, L. (2017) Employability, Managerialism, and Performativity in Higher Education: A Relational Perspective. Higher Education, 74 (4), 687-99.

Karliner, J. (1994). CorpWatch : INDIA: Setting the Record Straight. Corpwatch.org. Retrieved 15 January 2018, from http://www.corpwatch.org/article.php?id=11735

Kilduff, M., \& Mehra, A. (1997). Postmodernism and Organizational Research. The Academy of Management Review, 22(2), 453-481.

Killian, S. (2010). "No accounting for these people": Shell in Ireland and accounting language. Critical Perspectives on Accounting, 21(8), 711-723.

Koornhof, C., \& De Villiers, C.J. (1999). Postmodernism and accounting: Mirror or myth?, Meditari Accountancy Research, 7, 145-164.

Lai, A., Leoni, G., \& Stacchezzini, R. (2014). The socializing effects of accounting in flood recovery. Critical Perspectives on Accounting, 25(7), 579-603

Lal, N. (2017). Bhopal Gas Tragedy Still Haunts India. The Diplomat. Retrieved 15 January 2018, from https://thediplomat.com/2017/04/bhopal-gas-tragedy-still-haunts-india/.

Lapierre, D., \& Moro, J. (2003). Five Past Midnight in Bhopal. London: Scribner. 
Lehman, C., \& Okcabol, F. (2005). Accounting for crime. Critical Perspectives on Accounting, 16(5), 613-639.

Lyotard, J. F. (1984 [1979]). The Postmodern Condition: A Report on Knowledge (G. Bennington and B. Massumi trans.) Manchester: Manchester University Press.

Macintosh, N.B., Shearer, T., Thornton, D.B., \& Welker, M. (2000). Accounting as simulacrum and hyperreality: perspectives on income and capital. Accounting Organizations and Society, 25(1), 13-50.

Malla, T. M., Senthilkumar, C. S., Sharma, N. C. \& Ganesh, N. (2011) Chromosome instability among Bhopal gas tragedy survivors. American-Eurasian Journal of Toxicological Sciences, 3(4), 245-249.

Marcus, A.A., \& Goodman, R. (1989). Corporate adjustments to catastrophe: a study of investor reaction to Bhopal. Industrial Crisis Quarterly, 3(3), 213-234.

Marcus, A.A., \& Goodman, R.S. (1991). Victims and shareholders: the dilemmas of presenting corporate policy during a crisis. Academy of Management journal. Academy of Management, 34(2), 281-305.

Matilal, S., \& Höpfl, H. (2009). Accounting for the Bhopal disaster: footnotes and photographs. Accounting, Auditing \& Accountability Journal, 22(6), 953-972.

Mattessich, R. (2003). Accounting representation and the onion model of reality: a comparison with Baudrillard's orders of simulacra and his hyperreality. Accounting, Organizations and Society, 28(5), 443.

McKernan, J.F. \& Kosmala, K. (2007). Doing the truth: religion - deconstruction - justice, and accounting. Accounting, Auditing \& Accountability Journal, 20(5), 729-764. 
Miller, P., \& O'Leary, T. (1987). Accounting and the construction of the governable person. Accounting, Organizations and Society, 12(3), 235-265.

Mishra, P.K., Dabadghao, S., Modi, G.K., Desikan. P., Jain, A., \& Mittra, I. (2009). In utero exposure to methyl isocyanate in the Bhopal gas disaster: evidence of persisting hyperactivation of immune system two decades later. Occup Environ Med. 66(4), 279.

Mishra, M. C. (2019) A new generation inherits poisoned genes of Bhopal gas tragedy, and the broken promises of govts too. Firstpost. Retrieved 15 May 2019, from https://www.firstpost.com/politics/a-new-generation-inherits-poisoned-genes-of-bhopal-gastragedy-and-the-broken-promises-of-govts-too-6146901.html

Mody, C.P. (1980). Telex to R K Dutta, Sambhavna Trust Documentation Centre

Murthy, R. S. (2014). Mental health of survivors of 1984 Bhopal disaster: A continuing challenge. Industrial Psychiatry Journal, 23(2), 86-93.

Natarajan, R. (1981). Telex to W R Correa, Sambhavna Trust Documentation Centre.

Natarajan, R. (1984a). A Review of U C India Ltd's Ag Products Business, Sambhavna Trust Library.

Natarajan, R. (1984b). Letter to K S Kamdar for dismantling of Bhopal plant, Sambhavna Trust Library.

Nola, R., \& Irzik, G. (2003). Incredulity towards Lyotard: a critique of a postmodernist account of science and knowledge. Studies in History and Philosophy of Science, 34, 391-421.

Paparone, C. (2017). How we fight: A critical exploration of US military doctrine." Organization, 24 (4), 516-33. 
Paul, T. \& Baxi, U. (2015). Mass Disasters and Multinational liability: The Bhopal case. New Delhi: Indian Law Institute, New Delhi.

Perkiss, S., \& Moerman, L. (2017). Hurricane Katrina: exploring justice and fairness as a sociology of common good(s). Critical Perspectives on Accounting, in press.

Perkiss, S., \& Moerman, L. (2018). A dispute in the making: A critical examination of displacement, climate change and the Pacific Islands. Accounting, Auditing \& Accountability Journal, 31(1), 166-192.

Peters, M. (1989). Techno-science, rationality, and the university: Lyotard on the "postmodern condition." Educational Theory, 39(2), 89-105.

Peters, M. (1997, March). Lyotard, Education, and the Problem of Capitalism in the Postmodern Condition. Paper presented at the Annual Meeting of the American Educational Research Association. Retrieved 21 April 2018, from

https://files.eric.ed.gov/fulltext/ED408657.pdf

Press Trust of India. (2012). No contract was given to dispose of Bhopal toxic waste: German firm. NDTV.com. Retrieved 15 January 2018, from https://www.ndtv.com/bhopal-news/nocontract-was-given-to-dispose-of-bhopal-toxic-waste-german-firm-500067.

Press Trust of India (PTI). (2016). 32 Years On, Bhopal Gas Victims Still Await Justice. NDTV.com. Retrieved 7 March 2018, from_https://www.ndtv.com/india-news/32-years-onbhopal-gas-victims-still-await-justice-1633322.

Press Trust of India (PTI). (2017). 33 Years On, Bhopal Gas Tragedy Victims Seek Rehab Of Kids With Deformities. NDTV.com. Retrieved 7 March 2018, from https://www.ndtv.com/india-news/33-year-on-bhopal-gas-tragedy-victims-seek-rehab-ofkids-with-deformities-1783097.

Provide clean drinking water, demand Bhopal gas tragedy survivors. (2015). The Hindustan Times. Retrieved 7 March 2018, from https://www.hindustantimes.com/bhopal/provide-clean- 
drinking-water-demand-bhopal-gas-tragedy-survivors/story-

bYbf8HdRAQSP8oplreEB5I.html.

Preston, A., Wright, C., \& Young, J. (1996) Imag[in]ing annual reports. Accounting, Organizations and Society, 21(1), 113-137.

Raizada, J.K. \& Dwivedi, P.C. (1987). Chronic ocular lesions in Bhopal gas tragedy. Indian journal of ophthalmology, 35(5-6), 453-454.

Ramesh, R. (2009). Bhopal water still toxic 25 years after deadly gas leak, study finds. The Guardian. Retrieved 7 March 2018, from

https://www.theguardian.com/world/2009/dec/01/bhopal-chemical-studies-toxic-levels

Reich, M.R. \& Bowonder, B. (1992). Environmental Policy in India. Policy studies journal: the journal of the Policy Studies Organization, 20(4),643-661.

Revellino, S., \& Mouritsen, J. (2015). Accounting as an engine: The performativity of calculative practices and the dynamics of innovation. Management Accounting Research, 28, September, 31-49.

Rose, N. (1991). Governing by the numbers: Figuring out democracy. Accounting, Organizations and Society, 16, 673-692.

Rosenau, P. (1992). Post-Modernism and the Social Sciences. Princeton: Princeton University Press.

Rowlands, J. (2012). Accountability, quality assurance and performativity: The changing role of the academic board, Quality in Higher Education, 18 (1), 97-110.

Sambhavna, Water Contamination. (2019). Contamination spreads even further in Bhopal. The Bhopal Medical Appeal. Retrieved 16 August 2019, from https://www.bhopal.org/contamination-spreads-even-further-in- 
bhopal/?utm_source=Main+E-Newsletter+List\&utm_campaign=c79d9ee3f8-

EMAIL_CAMPAIGN_2019_06_05_10_06\&utm_medium=email\&utm_term=0_53f72ad444 -c79d9ee3f8-

Sargiacomo, M. (2014). Accounting for Natural Disasters \& Humanitarian InterventionsEditorial. Critical Perspectives on Accounting, 25(7), 576-578.

Sargiacomo, M. (2015). Earthquakes, exceptional government and extraordinary accounting. Accounting, Organizations and Society, 42, April, 67-89.

Sargiacomo, M., Ianni, L., \& Everett, J. (2014). Accounting for suffering: Calculative practices in the field of disaster relief. Critical Perspectives on Accounting, 25(7), 652-669.

Savage, A. A. (1995). A postmodern perspective on the scientific status of accounting: A research note. De Ratione, 9(1), 1-8.

Shrivastava, P. (1987). Bhopal: Anatomy of a crisis. Cambridge, Mass: Ballinger Pub. Co.

Shrivastava, R. (2011). Bhopal Gas Disaster: Review on Health Effects of Methyl Isocyanate. Research Journal of Environmental Sciences, 5(2), 150-156.

Siddiqui, J., \& Uddin, S. (2016). Human rights disasters, corporate accountability and the state: Lessons learned from Rana Plaza. Accounting, Auditing \& Accountability Journal, 29(4), 679704.

Singh, M. (2012). Bhopal gas victims see a ray of hope. The Hindu. Retrieved 15 January 2018, from http://www.thehindu.com/todays-paper/tp-national/bhopal-gas-victims-see-a-ray-ofhope/article3389396.ece

Sikka, P. (2015). The hand of accounting and accountancy firms in deepening income and wealth inequalities and the economic crisis: some evidence. Critical Perspectives on Accounting, 30, July, 46-62. 
Spicer, A., Alvesson, M. \& Kärreman, D. (2009) Critical performativity: The unfinished business of critical management studies. Human Relations 62(4), 537-560.

Sriramachari, S. (2005). Bhopal gas tragedy: scientific challenges and lessons for future. Journal of Loss Prevention in the Process Industries, 18(4-6), 264-267.

Taylor, D., Tharapos, M., \& Sidaway, S. (2014). Downward accountability for a natural disaster recovery effort: Evidence and issues from Australia's Black Saturday. Critical Perspectives on Accounting, 25(7), 633-651

Trotter, R.C., Day, S.G. \& Love, A.E. (1989). Bhopal, India and Union Carbide: The second tragedy. Journal of Business Ethics: 8(6), 439-454.

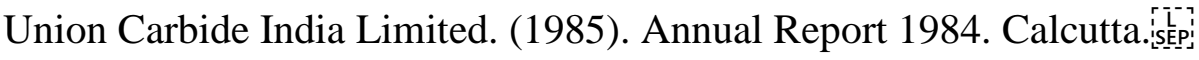

Union Carbide Corporation. (1985). Annual Report 1984. Houston.

Union Carbide Eastern. (1973). UCIL MIC based Ag Chem Project - Capital Budget Proposal, Sambhavna Trust Library.

Union Carbide India Limited. (1977). Review of the Capital Budget Proposal for the MIC based Agricultural Chemicals Project, Sambhavna Trust Library.

Union Carbide India Limited. (1981). UCIL-APD Strategic Plan, Sambhavna Trust Library.

Varma, S. (2013). Justice delayed: No hearing on plea for Bhopal gas relief in 3 years. The Times of India. Retrieved 15 January 2018, from https://timesofindia.indiatimes.com/india/Justice-delayed-No-hearing-on-plea-for-Bhopalgas-relief-in-3-years/articleshow/26755200.cms 
Vaidyanathan, A. (2012). Water around Union Carbide factory in Bhopal is dangerous: Report in Supreme Court. NDTV.com. Retrieved 15 January 2018, from https://www.ndtv.com/indianews/water-around-union-carbide-factory-in-bhopal-is-dangerous-report-in-supreme-court500136.

Vosselman, E. (2014). The "performativity thesis" and its critics: Towards a relational ontology of management accounting. Accounting and Business Research, 44(2), 181-203.

Walker, S. (2014). Drought, resettlement and accounting. Critical Perspectives on Accounting, 25(7), 604-619.

Weick, K. E. (1988). Enacted Sensemaking in Crisis Situations. Journal of Management Studies, 25 (4), 305-317.

Weick, K. E. (2010). Reflections on Enacted Sensemaking in the Bhopal Disaster. Journal of Management Studies, 47(3), 537-550.

Wittgenstein, L. (1963 [1953]). Philosophical investigations (G. E. M. Anscombe trans.) Oxford: Basil Blackwell.

Zavestoski, S. (2009). The Struggle for Justice in Bhopal: A New/Old Breed of Transnational Social Movement. Global social policy, 9(3), 383-407. 


\section{Appendix}

Table 1: Details of data sources

\begin{tabular}{|c|c|c|}
\hline Documents & Number & Source \\
\hline UCIL Annual Report 1984 & 1 & $\begin{array}{l}\text { The National Library of India, Kolkata, } \\
\text { India }\end{array}$ \\
\hline UCC Annual Report, 1984 & 1 & $\begin{array}{l}\text { University of Arkansas Library, } \\
\text { Arkansas, US }\end{array}$ \\
\hline $\begin{array}{l}\text { UCIL MIC based Ag Chem Project - } \\
\text { Capital Budget Proposal (1973) }\end{array}$ & 1 & $\begin{array}{l}\text { The Sambhavna Trust Library, Bhopal, } \\
\text { India }\end{array}$ \\
\hline $\begin{array}{l}\text { Review of the Capital Budget Proposal } \\
\text { for the MIC based Agricultural } \\
\text { Chemicals Project (1977) }\end{array}$ & 1 & $\begin{array}{l}\text { The Sambhavna Trust Library, Bhopal, } \\
\text { India }\end{array}$ \\
\hline UCIL-APD Strategic Plan (1981) & 1 & $\begin{array}{l}\text { The Sambhavna Trust Library, Bhopal, } \\
\text { India }\end{array}$ \\
\hline Safety Audit Report (1982) & 1 & $\begin{array}{l}\text { The Sambhavna Trust Library, Bhopal, } \\
\text { India }\end{array}$ \\
\hline Telexes & 14 & $\begin{array}{l}\text { The Sambhavna Trust Library, Bhopal, } \\
\text { India }\end{array}$ \\
\hline $\begin{array}{l}\text { Memorandum from UCC Engineering } \\
\text { dated 22/09/1975 }\end{array}$ & 1 & $\begin{array}{l}\text { The Sambhavna Trust Library, Bhopal, } \\
\text { India }\end{array}$ \\
\hline $\begin{array}{l}\text { Letter from E Munoz to Export-Import } \\
\text { Bank of the United States dated } \\
08 / 09 / 1975\end{array}$ & 1 & $\begin{array}{l}\text { The Sambhavna Trust Library, Bhopal, } \\
\text { India }\end{array}$ \\
\hline $\begin{array}{l}\text { Letter from R Natarajan to J B Law, the } \\
\text { Chairman of UCE dated 24/02/1984 }\end{array}$ & 1 & $\begin{array}{l}\text { The Sambhavna Trust Library, Bhopal, } \\
\text { India }\end{array}$ \\
\hline $\begin{array}{l}\text { Committee Hearings of the US House } \\
\text { of Representatives }\end{array}$ & 1 & $\begin{array}{l}\text { The Sambhavna Trust Library, Bhopal, } \\
\text { India }\end{array}$ \\
\hline
\end{tabular}


UCC Press Conference, Danbury, 19851

Employee testimony

The Sambhavna Trust Library, Bhopal, India

The Sambhavna Trust Library, Bhopal, India

Interview of $\mathrm{T} R$ Chouhan by the 1 Bhopal Group for Information and The Sambhavna Trust Library, Bhopal, India

\begin{tabular}{|c|c|c|}
\hline Interviews & Number & Date and venue \\
\hline Former employees & 5 & August 2018, Bhopal, India \\
\hline Survivors of the tragedy & 8 & August 2018, Bhopal, India \\
\hline
\end{tabular}




\section{After Bhopal}

B hopal was a shocking tragedy, but Union Carbide was well served by our quick and compassionate response, and by the way the situation was managed. We moved swiftly to provide emergency relief while concentrating management of the crisis among a small group of executives, so that unaffected businesses could proceed with their normal routines.

Many were shocked that the accident had happened to Union Carbide, a company with an excellent safety record. Expressions of support for Carbide poured in from customers, suppliers, and friends around the world. Carbide was also sustained by the performance of our employees, who never faltered throughout the December crisis.

On the issue of compensation for the Bhopal victims, we agree with many outside observers that a quick and fair settlement of the claims of all victims would serve their needs far better than prolonged and expensive litigation.

Bhopal will reverberate in areas other than compensation, however. The issues raised by the tragic accident will affect the public policy landscape for the chemical industry worldwide, and lead to review, by multinational companies and host countries alike, of the ground rules governing foreign investment and operations.

So although the immediate crisis is past, Union Carbide will be dealing with aspects of Bhopal for the foreseeable future. In particular, we expect to play an important role in the re-evaluation of regulations and policies, a re-evaluation we believe can lead to constructive dialogue. And we pledge to aid the chemical industry in its efforts to fully educate the public on the industry's dedication to safety.

It is important for the public to appreciate the chemical industry's commitment to high standards of quality and safety, for society depends on chemicals and chemical technologies for an array of products without which modern living standards would not be possible.

The industry also makes very significant economic contributions to the countries in which it op. erates. It is and will remain a big provider of jobs, a major contributor to national wealth and an important supplier to dozens of new and traditional industries that could not exist without chemicals.

The chemical industry has an outstanding safety record, yet most companies, including Union Carbide, regard that record as a base on which to build. In the aftermath of Bhopal, many companies began thorough reviews of their operations.

At Carbide, while continuing our regular safety audits, we have begun a special worldwide risk assessment study. Its purpose is to confirm that all our affliated facilities around the globe, where toxic or hazardous materials are manufactured, used, or stored, are being run according to health, safety and environmental standards which protect both plant personnel and local residents, and which are sensitive to public perceptions of what is needed.

While reviewing their operations, individual companies, and the industry as a whole, are also preparing to review the public policy environment for chemicals.

For example, we and other companies are continuing to discuss appropriate early warning and preparedness programs with the communities that live side by side with the chemical industry. On the legislative side, we expect review of communities' right to know what chemicals are being manufactured nearby, what the risks may be, and what steps have been taken to minimize them.

It is clear that chemical facilities and the com. munities they reside in can benefit from a closer relationship. On the one hand, safety considerations require coordination and communication between plant and community. And beyond that, lack of information may serve to generate unreasonable fear in the community, which can undermine operations at the plant and ultimately harm the local economy as well.

Yet the goal of having communities well informed could itself be undermined if standards and procedures become a patchwork that can change from place to place. Carbide will therefore support a compatible, nationwide system of hazard communications that provides employees and public authorities alike with the information they need to evaluate risks that chemical facilities may pose to health or the environment, and the safety measures and standards employed to control them.

The transport of hazardous chemicals is a related issue receiving increased attention in the aftermath of the accident. The transportation issue was underlined after Bhopal by the refusal of authorities in two countries to accept shipments of methyl isocyanate, the material that escaped from the Union Carbide India Limited (UCIL) plant, which Carbide had been moving safely and routinely to several locations in the United States and abroad for many years.

Few concerns receive more industry attention than transportation safety. The U.S. chemical industry has spent many millions of dollars for im. provements and safeguards on the railway cars that carry chemicals. The industry also devised Chemtrek, a 24-hour phone-in system that loca authorities may consult for advice and instructions 
on handling a chemical leak or spill. If Carbide materials are involved, Chemtrek activates our HELP system, which is designed to bring Carbide experts quickly to the scene to help direct containment and safety operations.

Yet the industry recognizes an obligation to search for ways to make transportation safer still. An approach Carbide employs for certain chemicals is a system of "engineered routing," which chooses the safest route based on a range of factors including traffic patterns, route hazards, dis. tance from populous areas, and the location of trained emergency teams.

Does the system have wider application? Can training be intensified for community authorities and for people involved in the transport of hazardous materials? Can regulations governing the transport of hazardous materials be improved? We expect the industry and authorities to consider al of these possibilities and more as the transportation issue continues to be addressed.

Bhopal will also have an effect on the work of U.S. government agencies involved in the regulaton of hazardous materials. Many have already urged the Environmental Protection Agency to move more quickly to update its list of hazardous air pollutants. Carbide also favors faster action on that task.

We believe the public has a right to feel confident that controls of hazardous pollutants are in place and are working. People must therefore also feel confident that the EPA and other agencies charged with health and environmental responsiblities can be relied upon to do their jobs. Carbide believes that it is in the best interest of the chemical industry as well to have a strong and respected EPA - one with a reputation for decisive action and sensitivity to public concerns.

But the accident did not happen in the United States; it happened in India, which has led some to raise questions about the presence of multinafional companies and their technologies in devel. oping countries, and the rules and regulations under which multinationals must operate.

In the rush to judgment after Bhopal, some said that India was victimized by technology. We think a more realistic view is the one expressed by an editorial in the Detroit News, which pointed out that India's "green revolution" could not have happened without pesticides and other technology. It's been estimated that pesticides save about 10 percent of the annual food crop in India, enough to leed over 70 million people.

Without the technologies and the capital that multinationals help to introduce, developing countries would have little hope of eradicating poverty and hunger. Most know this and encourage the inIroduction of new technology. But in the aftermath of Bhopal, both multinational corporations and host countries will be focusing anew on the important question: What are the best arrangements for accomplishing the safe operation of sophisticated technologies in developing countries?

It is ironic that this question should stem from an accident in India, a country which takes much pride in its educational system and in the efforts it has made to industrialize, and which has actively encouraged the importation of technology in recent years. Certainly our experience with UCIL, the Union Carbide subsidiary that owns and operates the Bhopal plant, has been a positive one. UCIL managers whose performance we have observed have been well-qualified for their positions. And UCIL management, particularly at the senior corporate level, has had an excellent record of performance.

Still, it has been argued that in many countries outside the industrialized West. the cultural background or basic educational level simply cannot support the ongoing operation of sophisticated. technologies. And it is a fact that in some countries, local laws require that new facilities be built and operated with local labor or materials, or that they be managed or staffed exclusively by nationals of the host country

These points are being raised in a number of quarters; they need clear-eyed review by all companies that do business around the world, and by host countries everywhere. If the international transfer of technology were to be disrupted by the calamity at Bhopal, that would represent a further loss in places where jobs and investment are badly needed. On the other hand, if Bhopal en. courages all parties to rethink safety policies and practices everywhere, it will have taught a valuable lesson.

All involved must do what it takes to make sure that no such accident can happen again. At Carbide we are optimistic that as many of these public policy issues are resolved, and as the chemical industry undertakes new initiatives to further reduce risk, its contribution - and ours to improved living standards around the world will continue to grow.

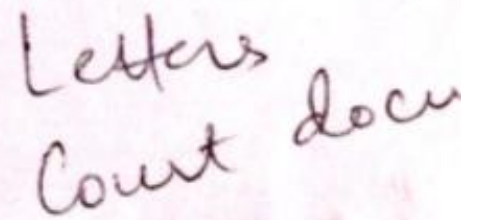

